\title{
Review \\ Genus Parkia: Phytochemical, Medicinal Uses, and Pharmacological Properties
}

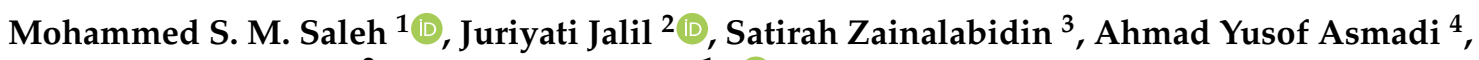 \\ Nor Hidayah Mustafa ${ }^{2}$ and Yusof Kamisah $1, *$ (D) \\ 1 Department of Pharmacology, Faculty of Medicine, Universiti Kebangsaan Malaysia, \\ Cheras, Kuala Lumpur 56000, Malaysia; medsaleh@ukm.edu.my \\ 2 Drug and Herbal Research Centre, Faculty of Pharmacy, Universiti Kebangsaan Malaysia, \\ Kuala Lumpur 50300, Malaysia; juriyatijali1@ukm.edu.my (J.J.); norhidayahmustafa91@gmail.com (N.H.M.) \\ 3 Program of Biomedical Science, Centre of Toxicology and Health Risk Study, Faculty of Health Sciences, \\ Universiti Kebangsaan Malaysia, Kuala Lumpur 50300, Malaysia; satirah@ukm.edu.my \\ 4 Unit of Pharmacology, Faculty of Medicine and Defence Health, Universiti Pertahanan Nasional Malaysia, \\ Kem Sungai Besi, Kuala Lumpur 57000, Malaysia; draayusof@gmail.com \\ * Correspondence: kamisah_y@ppukm.ukm.edu.my; Tel.: +603-91459575; Fax: +603-91459547
}

Citation: Saleh, M.S.M.; Jalil, J.; Zainalabidin, S.; Asmadi, A.Y.; Mustafa, N.H.; Kamisah, Y. Genus Parkia: Phytochemical, Medicinal Uses, and Pharmacological Properties. Int. J. Mol. Sci. 2021, 22, 618. https://doi.org/10.3390/ijms22020618

Received: 25 December 2020 Accepted: 7 January 2021 Published: 9 January 2021

Publisher's Note: MDPI stays neutral with regard to jurisdictional clai$\mathrm{ms}$ in published maps and institutional affiliations.

Copyright: (C) 2021 by the authors. Licensee MDPI, Basel, Switzerland. This article is an open access article distributed under the terms and conditions of the Creative Commons Attribution (CC BY) license (https:// creativecommons.org/licenses/by/ $4.0 /)$.

\begin{abstract}
The genus Parkia (Fabaceae, Subfamily, Mimosoideae) comprises about 34 species of mostly evergreen trees widely distributed across neotropics, Asia, and Africa. This review aims to provide an overview of the current status of the species from the genus Parkia in terms of its relationship between its phytochemistry and medical uses. Comprehensive information on Parkia species was retrieved from electronic databases, which were Web of Science, ScienceDirect, PubMed, and Google Scholar. This review identified nine species from genus Parkia with properties of medicinal use. They are used traditionally to treat several ailments, such as diabetes, diarrhea, wounds, hypertension, cough, chronic piles, conjunctivitis, and measles. The most common species studied are P. biglobosa, P. speciosa, P. javanica, P. bicolor, P. biglandulosa, P. filicoidea, and P. clappertoniana. A considerable number of secondary metabolites, such as terpenoids, phenolic acids, flavonoids (aglycone and glycosides), and numerous volatile compounds have been identified in this genus, which are responsible for their diverse pharmacological activities. Their extracts, pure compounds and seed lectins have been reported for their anticancer, antimicrobial, antihypertensive, antiulcer, antidiabetic, anti-inflammatory, antioxidant, antimalarial, hepatoprotective, and antidiarrheal activities. The information gathered in this review might be of help for future studies in terms of the current knowledge on the link between the phytochemical components and medicinal uses. This could facilitate more discoveries on its potentials particularly in the pharmacological characteristics and potential to be developed into modern medicines.
\end{abstract}

Keywords: Parkia; Mimosoideae; traditional medicine; secondary metabolite; pharmacological activities

\section{Introduction}

Parkia is a genus of flowering plants belonging to the family Fabaceae (subfamily, Mimosoideae) with pan-tropical distribution [1]. The word Parkia was named after the Scottish explorer Mungo Park, who drowned in the Niger River, Nigeria in January 1805 [2]. Thirty-one species from this genus were reported in 1995 [3]. Another four more species were discovered in 2009 [4]. Out of these species, 10 species found in Asia, four in Africa, and 20 in neotropics. Meanwhile, according to a plant list (2018), 80 scientific names are recorded from the genus Parkia containing 41 accepted names and 39 synonym species (The Plant List, 2018). These plants bear fruits called pods. Each pod contains up to 25-30 seeds. Many species from Parkia have been reported to be rich in carbohydrate [5-7], protein [8-10] and minerals [11-14]. 
From our extensive research regarding the biological, pharmacological, and phytochemical constituents of species from the genus Parkia, only 12 species have been scientifically investigated so far. Out of these, nine were studied on phytochemical analysis and determination of biological activities, which include P. bicolor, P. biglobosa, P. biglandulosa, P. filicoidea, P. clappertoniana, $P$. javanica (synonyms: P. roxburghii, P. timoriana), P. pendula, P. platycephala, and P. speciosa. The most frequently investigated over a wide range of ailments are $P$. biglobosa and $P$. speciosa. Studies on the remaining three species ( $P$. velutina, P. nitida, and P. polyads) focused on morphological variations and environmental distribution. This review aims to collate the present state of medicinal uses and phytochemistry of the genus Parkia for future studies. The link between the phytochemical components and medicinal uses of the current knowledge is discussed with the hope it would expedite more discoveries that have potentials to be developed into modern medicines.

\section{Methodology}

Information of the ethnobotanical use of plants from genus Parkia was retrieved from electronic databases which were ScienceDirect, Web of Science, Google Scholar, and PubMed, using search terms of "Parkia AND ethnobotanical", Parkia AND pharmacological", "Parkia AND pharmaceutical", "Parkia AND toxicological studies", "Parkia AND bioactivity", "Parkia AND phytochemistry", "Parkia AND ethnomedicinal", and "Parkia AND morphological". A total of 543 abstracts of research articles books, and conference papers published from 1961 to 2020 were obtained. Duplicates $(n=231)$ were removed. From the remaining 312 records, one hundred and two titles were excluded due to unavailability of full text or not published in English. Only articles and abstracts published in English were included. Two hundred and ten research articles and book chapters containing relevant and useful information were included in this review (Figure 1). Information gathered on the traditional uses, pharmacology and bioactive compounds identified from Parkia genus were summarized in the form of two tables and four figures. Chemical structures of bioactive compounds reported were drawn using ChemDraw software 16.0 (PerkinElmer Informatics, Waltham, MA, USA).

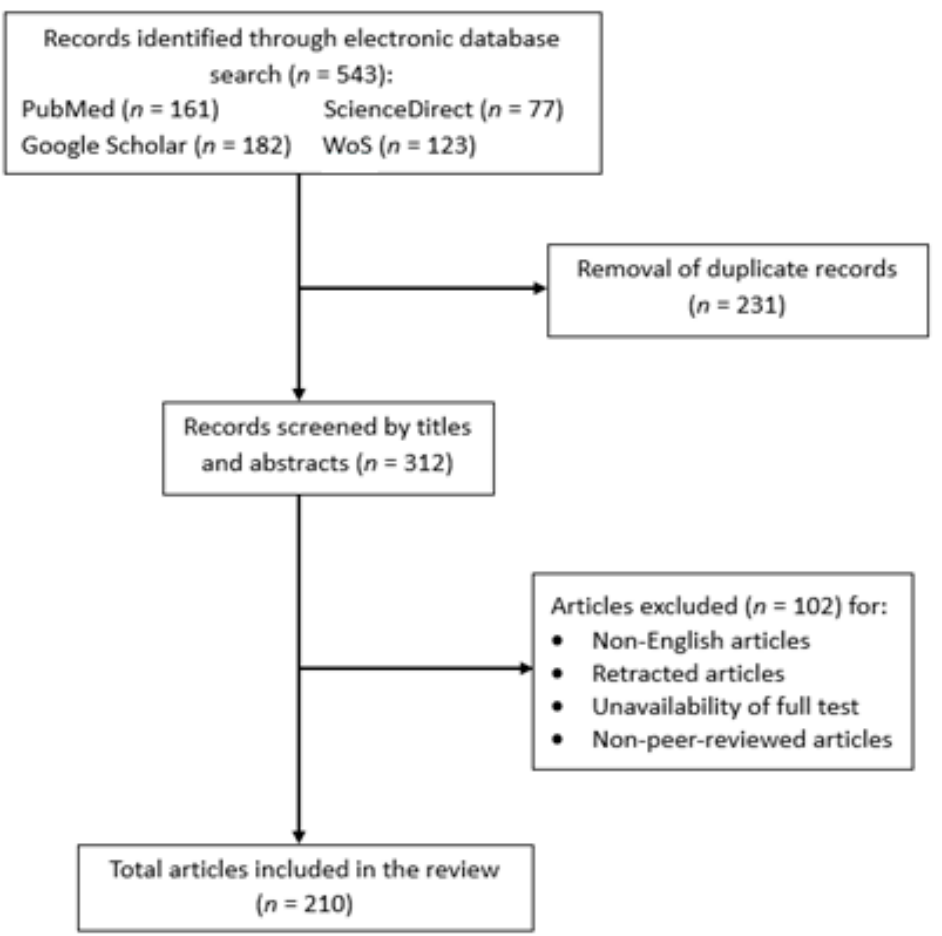

Figure 1. The preferred reporting items for systematic review and meta-analysis flowchart indicating the numbers of identified, screened, included and excluded articles in the review. 


\section{Traditional Medicinal Uses}

Parkia species are being used across all tropical countries to cure different ailments. Virtually, all parts of Parkia plants are utilized traditionally for different medicinal purposes. The materials of different parts of Parkia plants are processed as paste, decoction, and juice for the treatment of various ailments (Table 1). Almost all reported Parkia species are used in different forms to cure diarrhea and dysentery [15]. Different parts of P. biglobosa, P. clappertoniana, P. roxburghii, and P. speciosa are reported to be traditionally used for the treatment of diabetes [16-18]. Furthermore, skin-related diseases, such as eczema, skin ulcers, measles, leprosy, wound, dermatitis, chickenpox, scabies, and ringworm are treated using leaves, pods, and roots of P. speciosa and P. timoriana [19-21]. The stem barks of P. bicolor, P. clappertoniana, P. biglobosa, $P$. roxburghii as well as roots of $P$. speciosa are applied in the form of paste and decoction to treat different skin problems [22-25]. Decoction and paste of stem bark, pod, or root of P. biglobosa and P. speciosa are used to treat hypertension [22,26,27]. Moreover, stem barks of P. bicolor, P. biglobosa and leaves of P. speciosa are used for severe cough and bronchitis [28-30]. These aforementioned uses suggested that Parkia plants are likely to contain constituents with broad and diverse biological activities, such as antidiabetic, antimicrobial, antihypertensive, and anti-inflammatory.

\section{Phytochemistry of Genus Parkia}

Among the numerous species of Parkia plant, the chemistry of only few are known. However, different parts of the reported ones have been validated as good sources of phenolic compounds [11,31,32], saponins [33-35], terpenoids [35-37], steroids [23,38,39], tannins [38-40], fatty acids [23,41], and glycosides [42-44].

Various phytochemicals are found in the stem barks, leaves, seeds, and pods of these plants. The stem bark of $P$. biglobosa is reported to contain phenols, flavonoids, sugars, tannins, terpenoids, steroids, saponins [11,38], alkaloid, and glycosides [35,43,45], while the leaves contain glycosides, tannins, and alkaloids in trace amount $[11,23,46]$, in addition to flavonoids, phenols, and anthraquinones [47]. Phytochemical screening of the seeds shows the presence of saponins, alkaloids, flavonoids, polyphenols, terpenoids, glycosides and tannins $[48,49]$. Fermentation or roasting of P. biglobosa seeds results in the alteration of the bioactive components.

P. bicolor leaves contain chemical constituents similar to that of P. biglobosa such as glycosides, tannin, and alkaloids in trace amount [23]. The stem bark of P. bicolor contains alkaloids, tannins, saponins, glycosides, flavonoids, and terpenoids [35], while P. biglandulosa contains tannins, saponins, and glycosides, and P. filicoidea possesses flavonoids, sugars, saponins, and tannins [50]. The seed of P. javanica contains flavonoid, saponins, alkaloids, terpenoids, anthraquinones, steroids, and glycosides [44]. The pods are reported to have tannins, flavonoids, and saponins, all of which are significantly diminished when subjected to various processing methods, such as ordinary and pressure cooking methods [51,52]. Alkaloids, glycosides, saponins, and tannins are present in the whole plant of P. clappertoniana [31]. Phytochemical analysis of the leaves of P. platycephala revealed the presence of phenols, terpenoids, flavonoids [53], tannins and saponins [54]. Furthermore, flavonoids, alkaloids, phenols, and terpenoids were reported to be present in all parts of P. speciosa plant [37]. 
Table 1. The medicinal uses of plants from genus Parkia.

\begin{tabular}{|c|c|c|c|c|c|}
\hline Species & Part Used & Method of Preparation & Medicinal Uses & Region/Country & Reference \\
\hline \multirow[t]{4}{*}{ P. bicolor } & Stem bark & Pulverized powder & Wound healing & $\begin{array}{l}\text { West coast of Africa and } \\
\text { Nigeria }\end{array}$ & [23] \\
\hline & Tree & & Diarrhea, dysentery & Southwest Nigeria & [55] \\
\hline & Stem barks & Decoction & $\begin{array}{l}\text { Bad cough, measles, and } \\
\text { woman infertility }\end{array}$ & Cameroon & {$[28]$} \\
\hline & Stem barks & Decoction & Diarrhea and skin ulcers & Ghana & {$[56]$} \\
\hline \multirow{11}{*}{ P. biglobosa } & Seed and stem bark & Fresh seeds & Fish poison & West Africa & {$[57,58]$} \\
\hline & Root & $\begin{array}{l}\text { Decoction combined with } \\
\text { other plants }\end{array}$ & Infertility & Nigeria & [58] \\
\hline & & Bark infusion with lemon & Diarrhea & Nigeria & [59] \\
\hline & Stem bark & & Anti-snake venom & Nigeria & {$[60]$} \\
\hline & Bark & Paste, decoction & $\begin{array}{l}\text { Wound healing leprosy, hypertension, mouth } \\
\text { wash, toothpaste }\end{array}$ & Nigeria & {$[22,23]$} \\
\hline & Bark & Hot decoction & Fever & Gambia & [23] \\
\hline & Bark & Decoction & $\begin{array}{l}\text { Malaria, diabetes, amenorrhea, and } \\
\text { hypertension }\end{array}$ & $\begin{array}{l}\text { Senegal, Mali, Ghana Togo, } \\
\text { and South Africa }\end{array}$ & {$[11,40,61-63]$} \\
\hline & Roots and bark & $\begin{array}{l}\text { Decoction of the roots with } \\
\text { Ximenia americana }\end{array}$ & Weight loss & Burkina Faso & {$[64]$} \\
\hline & Stem bark & Boiled bark & $\begin{array}{c}\text { Diarrhea, conjunctivitis, severe cough, and } \\
\text { leprosy }\end{array}$ & West Coast Africa & {$[23,65,66]$} \\
\hline & Leaves & Decoction & Violent colic chest and muscular pain & Northern Nigeria & {$[38]$} \\
\hline & bark & Infusion & Dental caries and astringent & Guinea Bissau & [67] \\
\hline \multirow[t]{3}{*}{ P. biglandulosa } & Seed bark & Saponins & Astringent & India & [68] \\
\hline & Stem bark & & Hemagglutination, ulcer & India & [69] \\
\hline & Tree & & Inflammation and ulcer & India & [70] \\
\hline
\end{tabular}


Table 1. Cont.

\begin{tabular}{|c|c|c|c|c|c|}
\hline Species & Part Used & Method of Preparation & Medicinal Uses & Region/Country & Reference \\
\hline \multirow[t]{9}{*}{ P. clappertoniana } & Tree & & Hypertension & Southwest Nigeria & [55] \\
\hline & Root & & Dental caries and conjunctivitis & African & {$[71,72]$} \\
\hline & Seed & Crudely pounded & Labor induction & Ghana & [17] \\
\hline & Tree & & Diarrhea & Kaduna and Nigeria & [73] \\
\hline & Leaves and bark & Maceration & Epilepsy & Northern Nigeria & [74] \\
\hline & Stem bark & & Chickenpox and measles & Southwest Nigeria & [24] \\
\hline & Tree & & Mouthwash and toothache & Nigeria & [76] \\
\hline & Tree & & Eczema and skin diseases & Nigeria & [77] \\
\hline & Bark & Infusion & Hernia & Ghana & [75] \\
\hline \multirow[t]{2}{*}{ P. pendula } & Leaves bark & & Genital bath & Netherland & [78] \\
\hline & Bark & Decoction & Malaria & Brazil & [79] \\
\hline \multirow[t]{13}{*}{ P. speciosa } & Seed & $\begin{array}{c}\text { Eaten raw or cooked oral } \\
\text { decoction }\end{array}$ & Diabetes & Malaysia & [80] \\
\hline & Leaves & $\begin{array}{l}\text { Pounded with rice and applied } \\
\text { on the neck }\end{array}$ & Cough & Malaysia & [30] \\
\hline & Root & Decoction & Skin problems & Southern Thailand & [21] \\
\hline & Root & Decoction taken orally & Hypertension and diabetes & Malaysia & [26] \\
\hline & Fruit & Eaten raw & Diabetes & Malaysia & [30] \\
\hline & Seed & Eaten raw & Detoxification and hypertension & Singapore & [81] \\
\hline & & & Ringworm & Malaysia & [82] \\
\hline & Leaf & Decoction & Dermatitis & Indonesia & [20] \\
\hline & Root & Oral decoction & Toothache & Malaysia & [27] \\
\hline & Tree & & Heart problem, constipation and edema & India & {$[83,84]$} \\
\hline & Leaves & & Dermatitis & Indonesia & [85] \\
\hline & Seed & & Loss of appetite & Indonesia & [86] \\
\hline & Seed & Cooked & Kidney disorder & West Malaysia & [87] \\
\hline
\end{tabular}


Table 1. Cont

\begin{tabular}{|c|c|c|c|c|c|}
\hline Species & Part Used & Method of Preparation & Medicinal Uses & Region/Country & Reference \\
\hline \multirow[t]{6}{*}{ P. timoriana } & Bark and twig & Decoction of bark and twig paste & Diarrhea, dysentery, and wound & India & [88] \\
\hline & Bark & Decoction used to bath & Fever & Gambia & [89] \\
\hline & Pulp bark & Mixed with lemon & Ulcer and wound & Gambia & [89] \\
\hline & Fruit & & Diabetes & Thailand & [90] \\
\hline & Pod & Pounded in water & Hair washing, skin diseases, and ulcers & India & [19] \\
\hline & Bark and leaves & & Head washing, skin diseases, and ulcers & India & [19] \\
\hline \multirow[t]{6}{*}{ P. roxburghii } & Tree & Tender pod and bark taken orally & $\begin{array}{c}\text { Diarrhea, dysentery, intestinal disorder, and } \\
\text { bleeding piles }\end{array}$ & India & {$[91]$} \\
\hline & The fruit or young shoot & $\begin{array}{l}\text { Green portion of the fruit mixed } \\
\text { with water to be taken orally }\end{array}$ & $\begin{array}{l}\text { Dysentery, diarrhea, food poisoning, wound, } \\
\text { and scabies }\end{array}$ & India & [92] \\
\hline & Seed & $\begin{array}{l}\text { Grounded and mixed with hot } \\
\text { water }\end{array}$ & Postnatal care, diarrhea, edema and tonsillitis & Malaysia & [93] \\
\hline & Leaves, pod, peals, and bark & & Diarrhea and dysentery & India & [94] \\
\hline & Stem bark & Hot water extraction & Diarrhea and dysentery & India & [95] \\
\hline & Bark & Turn into paste & Used as plaster for eczema & India & [25] \\
\hline \multirow[t]{6}{*}{ P. javanica } & Bark, pod, and seed & Taking orally as vegetable & Dysentery and diarrhea & India & [15] \\
\hline & Tree & & Inflammation & India & [96] \\
\hline & Bark fruit & & Dysentery and piles & India & [51] \\
\hline & & & Stomachache and cholera & India & [97] \\
\hline & Bark and leaves & Lotion & Sores and skin diseases & & [98] \\
\hline & Tree & & Diarrhea, cholera dysentery, and food poisoning & India & [99] \\
\hline
\end{tabular}


Phytochemicals (primary and secondary metabolites) are well known for their vast medicinal benefits to plants and human [100]. The primary metabolites-such as carbohydrate, proteins, chlorophyll, lipids, nucleic, and amino acids [101-103] —are responsible for plants' biochemical reactions such as respiration and photosynthesis [102]. The secondary metabolites are majorly alkaloids, phenols, terpenoids, flavonoids, saponins, steroids, tannins, and glycosides, which play important roles in protecting the plants against damages and improving plant aroma, coloration and flavor [101,103], The phytochemicals are present in various parts of the plants especially in the three major parts viz. the leaves, stems and roots. Their percentage composition in each plant may vary depending on environmental conditions, variety and processing methods [101]. Previous studies have shown that phenolic compounds are the most abundant and widely distributed phytoconstituents (45\%), followed by steroids and terpenoids (27\%), and alkaloids (18\%) [101,104]. Alkaloids, flavonoids, tannins, and phenolic compounds are the most common constituents that have been studied in phytochemistry $[104,105]$. Several compounds from these classes have been identified and investigated from Parkia plants for various pharmacological activities. Despite the enormous reports on the phytochemical screening of different species from the genus Parkia, structure identification and purification of compounds from these species are scarcely reported compared to other genera. The compounds were identified using high-performance liquid chromatography with diode-array detector (HPLC-DAD), liquid chromatography mass spectrometry (LCMS), flow analysis-ionization electrospray ion trap tandem mass spectrometry (FIA-ESI-IT-MS), gas chromatography time-of-flight mass spectrometry (GC/ToF-MS), high-performance liquid chromatography-electrospray ion mass spectrometry (HPLC-ESI-MS), and chromatographic purification from the fraction and characterization through nuclear magnetic resonance (NMR).

\subsection{Polyphenolic Compounds}

Phenolic compounds found in Parkia species are grouped into simple phenol (10 and 31), phenolic acids 29-41, flavone 15-19 and 24, flavanone 25-26, flavonol 11-14 and 20-22, methoxyflavonol 23, as well as flavanol 1-10 (Table 2). Phenolic acids are mostly found in the pods and edible parts of Parkia, while polyphenolic compounds are present in the leaves, stem barks, roots, or seeds. The most commonly reported flavonoid in Parkia species are flavanol $\mathbf{1}$ and its isomer $\mathbf{8}$, which are obtained from the pod and bark of P. speciosa and P. biglobosa, respectively [106-108] and the remaining flavanols 11-18 are mainly galloylated catechins. Compound $\mathbf{1 1}$ is isolated from ethyl acetate fraction of $P$. roxburghii pod [18], while compounds 12-18 are identified from the ethyl acetate fraction of root/stem of P. biglobosa [18]. One methoxyflavonol 23, two flavanone $\mathbf{2 6 - 2 7}$ and isoflavones $\mathbf{2 7 - 2 8}$ are identified in the edible parts of P. javanica [108]. A new flavanone, naringenin-1-4'-di-O-BD-glucopyranoside $\mathbf{2 6}$ is isolated from $n$-butanol fraction of P. biglobosa [109], while a new phenylpropanoid is elucidated as 4-(3-hydroxypropyl)benzyl nonanoate from the leaves of $P$. javanica [110]. Isolation of compounds $\mathbf{4 2 - 4 3}$ for the first time as a pure compound was reported from the ethanol extract of $P$. biglobosa bark [111]. The structures of these compounds are illustrated in Figures 2 and 3. 
Table 2. Phytochemical compounds from Parkia.

\begin{tabular}{|c|c|c|c|c|c|}
\hline Structure Number & Type & Compound & Species & Part & Reference \\
\hline \multicolumn{6}{|c|}{ Polyphenolics } \\
\hline \multirow{3}{*}{1} & \multirow{3}{*}{ Flavanol } & \multirow{3}{*}{ Catechin } & P. speciosa & Pod & [107] \\
\hline & & & P. biglobosa & Root/bark & [106] \\
\hline & & & P. javanica & Edible part & [108] \\
\hline \multirow{2}{*}{2} & \multirow{2}{*}{ Flavanol } & \multirow{2}{*}{ Epicatechin } & P. speciosa & Pod & {$[107]$} \\
\hline & & & P. javanica & Edible part & [108] \\
\hline \multirow{2}{*}{3} & \multirow{2}{*}{ Flavanol } & \multirow{2}{*}{ Epigallocatechin } & P. biglobosa & Root/bark & [111] \\
\hline & & & P. javanica & Edible part & [108] \\
\hline \multirow{2}{*}{4} & \multirow{2}{*}{ Flavanol } & \multirow{2}{*}{ Epigallocatechin gallate } & P. roxburghii & Pod & {$[18]$} \\
\hline & & & P. biglobosa & Root/bark & {$[106,111]$} \\
\hline 5 & Flavanol & Epicatechin-3-O-gallate & P. biglobosa & Bark & [111] \\
\hline 6 & Flavanol & 4-O-methyl-epigallocate-chin & P. biglobosa & Bark & {$[111]$} \\
\hline 7 & Flavanol & Epigallocatechin-O-glucuronide & P. biglobosa & Root/bark & [106] \\
\hline 8 & Flavanol & Epicatechin-O-gallate-O-glucuronide & P. biglobosa & Root/bark & {$[106]$} \\
\hline 9 & Flavanol & $\begin{array}{l}\text { Epigallocatechin-O-gallate-O- } \\
\text { glucuronide } \\
\end{array}$ & P. biglobosa & Root/bark & {$[106]$} \\
\hline 10 & Flavanol & Theaflavin gallate & P. speciosa & Pod & [112] \\
\hline \multirow{2}{*}{11} & \multirow{2}{*}{ Flavonol } & \multirow{2}{*}{ Kaempferol } & P. speciosa & Pod & {$[107]$} \\
\hline & & & P. javanica & Edible part & {$[108]$} \\
\hline 12 & Flavonol & Quercetin & P. speciosa & Pod & [107] \\
\hline 13 & Flavonol & Hyperin & P. roxburghii & Pod & {$[18]$} \\
\hline 14 & Flavonol & Apigenin & P. speciosa & Pod & [112] \\
\hline 15 & Flavone & $3,7,3^{\prime}, 4^{\prime}$-Tetrahydroxyflavone & P. clappertoniana & Seeds & {$[113,114]$} \\
\hline 16 & Flavone & 7-Hydroxy-3, 8, 4' -trimethoxyflavone & P. clappertoniana & Leaves & {$[115]$} \\
\hline 17 & Flavone & $\begin{array}{c}\text { 2'-Hydroxy- } \\
3,7,8,4^{\prime}, 5^{\prime \prime} \text { pentamethoxyflavone }\end{array}$ & P. clappertoniana & Leaves & [115] \\
\hline 18 & Flavone & Nobiletin & P. speciosa & Pod & [112] \\
\hline 19 & Flavone & Tangeritin & P. speciosa & Pod & {$[112]$} \\
\hline \multirow{2}{*}{20} & \multirow{2}{*}{ Flavonol } & \multirow{2}{*}{ Myricetin } & P. javanica & Edible part & {$[108]$} \\
\hline & & & P. speciosa & Pod & [112] \\
\hline \multirow{2}{*}{21} & \multirow{2}{*}{$\begin{array}{l}\text { Flavonol } \\
\text { glycoside }\end{array}$} & \multirow{2}{*}{ Rutin } & P. javanica & Edible part & {$[108]$} \\
\hline & & & P. speciosa & Pod & {$[112]$} \\
\hline 22 & $\begin{array}{l}\text { Flavonol } \\
\text { glycoside }\end{array}$ & Didymin & P. speciosa & Pod & [112] \\
\hline 23 & $\begin{array}{l}\text { Methoxy } \\
\text { flavonol }\end{array}$ & Isorhamnetin & P. javanica & Edible part & [108] \\
\hline 24 & Flavone & Luteolin & P. javanica & Edible part & [108] \\
\hline 25 & Flavanone & Naringenin & P. javanica & Edible part & [108] \\
\hline 26 & Flavanone & $\begin{array}{l}\text { Naringenin-1-4'-di-O-ßs-D- } \\
\text { glucopyranoside }\end{array}$ & P. biglobosa & Fruit pulp & [109] \\
\hline 27 & Isoflavone & Genistein & P. javanica & Edible part & {$[108]$} \\
\hline 28 & Isoflavone & Daidzein & P. javanica & Edible part & [108] \\
\hline
\end{tabular}


Table 2. Cont.

\begin{tabular}{|c|c|c|c|c|c|}
\hline Structure Number & Type & Compound & Species & Part & Reference \\
\hline \multirow{2}{*}{29} & \multirow{2}{*}{ Phenolic acid } & \multirow{2}{*}{ Gallic acid } & P. speciosa & Pod & [107] \\
\hline & & & P. bicolor & Root & [28] \\
\hline 30 & Phenolic acid & Methyl gallate & P. bicolor & Root & [28] \\
\hline 31 & Phenolic acid & Hydroxybenzoic acid & P. speciosa & Pod & [107] \\
\hline 32 & Phenolic acid & Vanillic acid & P. speciosa & Pod & [107] \\
\hline \multirow{2}{*}{33} & \multirow{2}{*}{ Phenolic acid } & \multirow{2}{*}{ Chlorogenic acid } & P. speciosa & Pod & [107] \\
\hline & & & P. javanica & Edible part & [108] \\
\hline 34 & Phenolic acid & Ellagic acid & P. speciosa & Pod & [107] \\
\hline 35 & Phenolic acid & Punicalin & P. speciosa & Pod & [112] \\
\hline \multirow{2}{*}{36} & \multirow{2}{*}{ Phenolic acid } & \multirow{2}{*}{ Caffeic acid } & P. speciosa & Pod & [107] \\
\hline & & & P. javanica & Edible part & [108] \\
\hline 37 & Phenolic acid & Cinnamic acid & P. speciosa & Pod & [107] \\
\hline \multirow{2}{*}{38} & \multirow{2}{*}{ Phenolic acid } & \multirow{2}{*}{$P$-Coumaric acid } & P. speciosa & Pod & [107] \\
\hline & & & P. javanica & Edible part & [108] \\
\hline \multirow{2}{*}{39} & \multirow{2}{*}{ Phenolic acid } & Ferulic acid & P. speciosa & Pod & {$[107]$} \\
\hline & & & P. javanica & Edible part & [108] \\
\hline 40 & Phenolic acid & Coutaric acid & P. speciosa & Pod & [112] \\
\hline 41 & Phenolic acid & Caftaric acid & P. speciosa & Pod & [112] \\
\hline 42 & Phenolic & 1-(w-Feruloyllignoceryl) -glycerol & P. biglobosa & Bark & {$[111]$} \\
\hline 43 & Phenolic & 1-(w-Isoferuloylalkanoyl) -glycerol & P. biglobosa & Bark & {$[111]$} \\
\hline 44 & Phenolic & Malvidin & P. speciosa & Pod & [112] \\
\hline 45 & Phenolic & Primulin & P. speciosa & Pod & [112] \\
\hline 46 & Pheny propanoid & Parkinol & P. javanica & Leaves & [110] \\
\hline 47 & Phenol & 2-Methoxy phenol & P. biglobosa & Seed & [116] \\
\hline \multirow[t]{2}{*}{48} & Phenol & 2,4-Disiopropyl-phenol & P. biglobosa & Seed & [116] \\
\hline & & Terpenoid and steroid & & & \\
\hline \multirow{3}{*}{49} & \multirow{3}{*}{ Triterpenoid } & \multirow{3}{*}{ Lupeol } & P. biglobosa & Bark & [111] \\
\hline & & & P. bicolor & Root & [28] \\
\hline & & & P. speciosa & Seeds & {$[117]$} \\
\hline 50 & Monoterpenoid & Limonene & P. biglobosa & Seed & [116] \\
\hline 51 & Triterpenoid & Ursolic acid & P. javanica & Leaf/stem & [42] \\
\hline 52 & Triterpenoid & Parkibicoloroside A & P. bicolor & Root & {$[118]$} \\
\hline 53 & Triterpenoid & Parkibicoloroside B & P. bicolor & Root & [118] \\
\hline 54 & Triterpenoid & Parkibicoloroside C & P. bicolor & Root & [118] \\
\hline 55 & Triterpenoid & Parkibicoloroside D & P. bicolor & Root & {$[118]$} \\
\hline 56 & Triterpenoid & Parkibicoloroside E & P. bicolor & Root & {$[118]$} \\
\hline 57 & $\begin{array}{l}\text { Monoterpenoidal } \\
\text { glucoside }\end{array}$ & $\begin{array}{l}\text { 8-O-p-Hydroxl-6'-O-p-coumaryl- } \\
\text { missaeno-sidic acid }\end{array}$ & P. javanica & Leaf & [42] \\
\hline 58 & $\begin{array}{l}\text { Monoterpenoidal } \\
\text { glucoside }\end{array}$ & $\begin{array}{l}\text { 7-O-E-3,4-Dimethoxycinnamoyl-6' } \\
\text { O-ß-D-glucopyranosylloganic acid }\end{array}$ & P. javanica & Leaf & [42] \\
\hline
\end{tabular}


Table 2. Cont.

\begin{tabular}{|c|c|c|c|c|c|}
\hline Structure Number & Type & Compound & Species & Part & Reference \\
\hline 59 & Diterpene & $\begin{array}{l}\text { 16-O-Methyl-cass-13(15) } \\
\text { ene-16,18-dionic acid }\end{array}$ & P. bicolor & Root & [118] \\
\hline \multirow{3}{*}{60} & \multirow{3}{*}{ Steroid } & \multirow{3}{*}{$\beta$-Sitosterol } & P. speciosa & Seed & {$[117,119,120]$} \\
\hline & & & P. javanica & Leaf/stem & [42] \\
\hline & & & P. biglobosa & Seed oil & {$[121,122]$} \\
\hline \multirow{2}{*}{61} & \multirow{2}{*}{ Steroid } & \multirow{2}{*}{ Stigmasterol } & P. speciosa & Seed & {$[117,119,120]$} \\
\hline & & & P. biglobosa & Seed oil & {$[121,122]$} \\
\hline 62 & Steroid & Stigmasterol methyl ester & P. speciosa & Seed & {$[117,119]$} \\
\hline 63 & Steroid & Stigmast-4-en-3-one & P. speciosa & Seed & {$[123]$} \\
\hline 64 & Steroid & Stigmasta-5,24(28)-diene-3-ol & P. speciosa & Seed & [117] \\
\hline \multirow{2}{*}{65} & \multirow{2}{*}{ Steroid } & \multirow{2}{*}{ Campesterol } & P. speciosa & Seed & {$[117,119]$} \\
\hline & & & P. biglobosa & Seed oil & {$[121,122]$} \\
\hline \multirow[t]{3}{*}{66} & Steroid & Stigmastan-6,22-diien,3,6-dedihydo- & P. speciosa & Seed & [119] \\
\hline & \multicolumn{3}{|c|}{ Miscellaneous Compounds } & & \\
\hline & \multirow{3}{*}{ Fatty acid } & Arachidonic acid & P. speciosa & Seed & {$[117,119]$} \\
\hline \multirow[t]{2}{*}{67} & & & P. bicolor & Seed & {$[22]$} \\
\hline & & & P. biglobosa & Seed & [22] \\
\hline 68 & Fatty acid & Linoleic acid chloride & P. speciosa & Seed & {$[117,119]$} \\
\hline \multirow{3}{*}{69} & \multirow{3}{*}{ Fatty acid } & \multirow{3}{*}{ Linoleic acid } & P. speciosa & Seed & {$[117,119]$} \\
\hline & & & P. biglobosa & Seed & [22] \\
\hline & & & P. bicolor & Seed & {$[22]$} \\
\hline 70 & Fatty acid & Squalene & P. speciosa & Seed & {$[117,119]$} \\
\hline 71 & Fatty acid & Lauric acid & P. speciosa & Seed & {$[117,124]$} \\
\hline \multirow{3}{*}{72} & \multirow{3}{*}{ Fatty acid } & Stearic acid & P. speciosa & Seed & {$[117,119,124]$} \\
\hline & & & P. biglobosa & Seed & [22] \\
\hline & & & P. bicolor & Seed & {$[22]$} \\
\hline 73 & Fatty acid & Stearoic acid & P. speciosa & Seed & [124] \\
\hline 74 & Fatty acid & Eicosanic acid & P. speciosa & Seed & [124] \\
\hline 75 & Fatty acid & Oleic acid & P. speciosa & Seed & {$[117,119,124]$} \\
\hline \multirow{3}{*}{76} & \multirow{3}{*}{ Fatty acid } & \multirow{3}{*}{ Palmitic acid } & P. speciosa & Seed & {$[117,119,124]$} \\
\hline & & & P. biglobosa & Seed & [22] \\
\hline & & & P. bicolor & Seed & [22] \\
\hline 77 & Fatty acid & Myristic acid & P. speciosa & Seed & {$[117,119,124]$} \\
\hline 78 & Fatty acid & Undecanoic acid & P. speciosa & Seed & {$[119,124]$} \\
\hline 79 & Fatty acid & Stearolic acid & P. speciosa & Seed & [119] \\
\hline 80 & Fatty acid & Hydnocarpic acid & P. speciosa & Seed & [124] \\
\hline 81 & $\begin{array}{c}\text { Cyclic } \\
\text { polysulfide }\end{array}$ & 1,3-dithiabutane & P. speciosa & Seed & [125] \\
\hline 82 & $\begin{array}{c}\text { Cyclic } \\
\text { polysulfide }\end{array}$ & 2,4- Dithiapentane & P. speciosa & Seed & [125] \\
\hline 83 & $\begin{array}{c}\text { Cyclic } \\
\text { polysulfide }\end{array}$ & 2,3,5-Trithiahexane & P. speciosa & Seed & [125] \\
\hline
\end{tabular}


Table 2. Cont.

\begin{tabular}{|c|c|c|c|c|c|}
\hline Structure Number & Type & Compound & Species & Part & Reference \\
\hline 84 & $\begin{array}{c}\text { Cyclic } \\
\text { polysulfide }\end{array}$ & 2,4,6-Trithiaheptane & P. speciosa & Seed & [125] \\
\hline \multirow{2}{*}{85} & \multirow{2}{*}{$\begin{array}{c}\text { Cyclic } \\
\text { polysulfide }\end{array}$} & 1,2,4-Trithiolane & P. biglobosa & Seed & {$[116,126]$} \\
\hline & & & P. speciosa & Seed & {$[126-128]$} \\
\hline 86 & $\begin{array}{c}\text { Cyclic } \\
\text { polysulfide }\end{array}$ & 1,3,5-Trithiane & P. speciosa & Seed & [128] \\
\hline 87 & $\begin{array}{c}\text { Cyclic } \\
\text { polysulfide }\end{array}$ & 3,5-Dimethyl-1,2,4-trithiolane & P. speciosa & Seed & [128] \\
\hline 88 & $\begin{array}{c}\text { Cyclic } \\
\text { polysulfide }\end{array}$ & Dimethyl tetrasulfid & P. speciosa & Seed & [128] \\
\hline 89 & $\begin{array}{c}\text { Cyclic } \\
\text { polysulfide }\end{array}$ & 1,2,5,6-Tetrathio-cane & P. speciosa & Seed & {$[128]$} \\
\hline 90 & $\begin{array}{c}\text { Cyclic } \\
\text { polysulfide }\end{array}$ & 1,2,3,5-Tetrathiane & P. speciosa & Seed & [128] \\
\hline 91 & $\begin{array}{c}\text { Cyclic } \\
\text { polysulfide }\end{array}$ & 1,2,4,5-Tetrathiane & P. speciosa & Seed & {$[128]$} \\
\hline 92 & $\begin{array}{c}\text { Cyclic } \\
\text { polysulfide }\end{array}$ & 1,2,4,6-Tetrathie-pane & P. speciosa & Seed & {$[126,128]$} \\
\hline 93 & $\begin{array}{c}\text { Cyclic } \\
\text { polysulfide }\end{array}$ & $\begin{array}{c}1,2,4,5,7,8- \\
\text { Hexathiolnane }\end{array}$ & P. speciosa & Seed & {$[126]$} \\
\hline 94 & $\begin{array}{c}\text { Cyclic } \\
\text { poly-sulfide }\end{array}$ & Lenthionine & P. speciosa & Seed & $\begin{array}{c}{[117,124,126,} \\
128]\end{array}$ \\
\hline 95 & Esters & $n$-Tetradecyl acetate & P. speciosa & Seed & [124] \\
\hline 96 & Esters & Methyl linoleate & P. speciosa & Seed & [124] \\
\hline \multirow{2}{*}{97} & \multirow{2}{*}{ Esters } & Ethyl linoleate & P. speciosa & Seed & {$[117,124]$} \\
\hline & & & P. biglobosa & Seed & [116] \\
\hline 98 & Ester & Butyl palmitate & P. speciosa & Seed & [117] \\
\hline 99 & Esters & Ethyl palmitate & P. speciosa & Seed & [124] \\
\hline 100 & Esters & Methyl palmitate & P. speciosa & Seed & [124] \\
\hline 101 & Esters & Methyl laurate & P. speciosa & Seed & {$[124]$} \\
\hline 102 & Esters & Dodecyl acrylate & P. speciosa & Seed & [124] \\
\hline 103 & Esters & Methyl hexadecanoate & P. biglobosa & Seed & [116] \\
\hline 104 & Ester & Ethyl stearate & P. speciosa & Seed & {$[117,124]$} \\
\hline 105 & Ester & Methyl octadecanoate & P. biglobosa & Seed & [116] \\
\hline 106 & Ester & Butyl stearate & P. speciosa & Seed & {$[124]$} \\
\hline 107 & Ester & $\begin{array}{c}\text { Propanoic acid, } 3,3^{\prime} \text {-thiobis-didodecyl } \\
\text { ester }\end{array}$ & P. speciosa & Seed & {$[124]$} \\
\hline 108 & Ester & Linoleaidic acid methyl ester & P. speciosa & Seed & [119] \\
\hline 109 & Alcohol & 2,6,10,14-Hexadecatetraen-1-ol & P. speciosa & Seed & {$[117]$} \\
\hline 110 & Alcohol & 1-Octen-3-ol & P. biglobosa & Seed & [116] \\
\hline 111 & Alcohol & 3-Ethyl-4-nonanol & P. speciosa & Seed & {$[117]$} \\
\hline 112 & Alcohol & 1-Tridecanol & P. speciosa & Seed & {$[117,124]$} \\
\hline 113 & Acid & Eicosanoic acid & P. speciosa & Seed & [117] \\
\hline
\end{tabular}


Table 2. Cont.

\begin{tabular}{|c|c|c|c|c|c|}
\hline Structure Number & Type & Compound & Species & Part & Reference \\
\hline 114 & Acid & $\begin{array}{l}\text { 16-O-Methyl-cass-13(15)ene-16,18- } \\
\text { dionic acid }\end{array}$ & P. bicolor & Root & [118] \\
\hline 115 & Acid & Elaidic acid & P. speciosa & Seed & {$[117,124]$} \\
\hline 116 & Pyrazine & 2,5-Dimethyl pyrazine & P. biglobosa & Seed & [116] \\
\hline 117 & Pyrazine & Trimethyl pyrazine & P. biglobosa & Seed & [116] \\
\hline 118 & Pyrazine & 2-Ethyl-3,5-dimethyl pyrazine & P. biglobosa & Seed & [116] \\
\hline 119 & Ketone & 2-Nonade-canone & P. speciosa & Seed & {$[117,124]$} \\
\hline 120 & Ketone & 2-Pyrrolidi-none & P. speciosa & Seed & [117] \\
\hline 121 & Ketone & Cyclodecanone & P. speciosa & Seed & [124] \\
\hline 122 & Alkane & Cyclododecane & P. biglobosa & Seed & [116] \\
\hline 123 & Alkane & Tetradecane & P. speciosa & Seed & [119] \\
\hline 124 & $\begin{array}{l}\text { Benzene } \\
\text { glucoside }\end{array}$ & $\begin{array}{l}\text { 3,4,5-Trimethoxyphenyl-1-O-ß-D- } \\
\text { glucopy-ranoside }\end{array}$ & P. bicolor & Root & [118] \\
\hline 125 & Aldehyde & 2-Decenal & P. speciosa & Seed & [117] \\
\hline 126 & Aldehyde & Cyclo-decanone-2,4-decadienal & P. speciosa & Seed & [117] \\
\hline \multirow{2}{*}{127} & \multirow{2}{*}{ Aldehyde } & \multirow{2}{*}{ Pentanal } & P. biglobosa & Seed & [116] \\
\hline & & & P. speciosa & Seed & [125] \\
\hline 128 & Aldehyde & 3-Methylthio-propanal & P. biglobosa & Seed & [116] \\
\hline 129 & Aldehyde & Tetradecanal & P. speciosa & Seed & {$[119,124]$} \\
\hline 130 & Aldehyde & Pentadecanal & P. speciosa & Seed & {$[117,124]$} \\
\hline 131 & Aldehyde & Hexadecanal & P. speciosa & Seed & {$[117,124]$} \\
\hline 132 & Amine & Hexanamide & P. speciosa & Seed & [117] \\
\hline 133 & Oil & Vitamin E & P. speciosa & Seed & {$[117,124]$} \\
\hline
\end{tabular}


<smiles>[R6]c1cc(C2c3cc(O)cc(O)c3Oc3cc(O)cc([2H])c32)ccc1O</smiles>

\begin{tabular}{ccccc}
\hline & $\mathrm{R}_{1}$ & $\mathrm{R}_{2}$ & $\mathrm{R}_{3}$ & $\mathrm{R}_{4}$ \\
\hline 1 & $\mathrm{H}$ & $\mathrm{OH}$ & $\mathrm{H}$ & $\mathrm{H}$ \\
2 & $\mathrm{OH}$ & $\mathrm{H}$ & $\mathrm{H}$ & $\mathrm{H}$ \\
3 & $\mathrm{OH}$ & $\mathrm{H}$ & $\mathrm{H}$ & $\mathrm{OH}$ \\
4 & Galloyl & $\mathrm{H}$ & $\mathrm{H}$ & $\mathrm{OH}$ \\
5 & Galloyl & $\mathrm{H}$ & $\mathrm{H}$ & $\mathrm{H}$ \\
6 & $\mathrm{OH}$ & $\mathrm{H}$ & $\mathrm{OCH}_{3}$ & $\mathrm{OH}$ \\
\hline
\end{tabular}

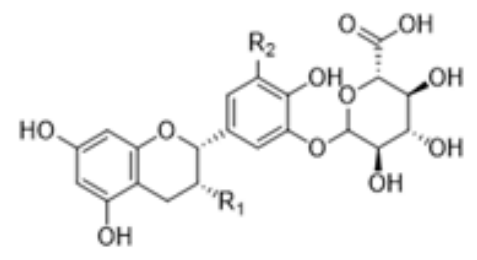

\begin{tabular}{ccc}
\hline & $\mathrm{R}$ & $\mathrm{R}$ \\
\hline 7 & $\mathrm{OH}$ & $\mathrm{H}$ \\
8 & Galloy1 & $\mathrm{H}$ \\
9 & Galloy1 & $\mathrm{OH}$ \\
\hline
\end{tabular}

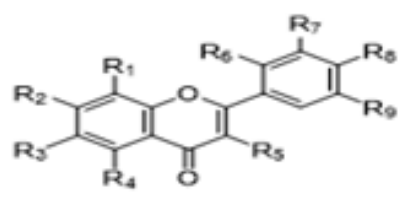

\begin{tabular}{cccccccccc}
\hline & $\mathrm{R}_{1}$ & $\mathrm{R}_{2}$ & $\mathrm{R}_{3}$ & $\mathrm{R}_{4}$ & $\mathrm{R}_{4}$ & $\mathrm{R}_{5}$ & $\mathrm{R}_{6}$ & $\mathrm{R}_{7}$ & $\mathrm{R}_{8}$ \\
\hline 11 & $\mathrm{H}$ & $\mathrm{OH}$ & $\mathrm{H}$ & $\mathrm{H}$ & $\mathrm{OH}$ & $\mathrm{H}$ & $\mathrm{H}$ & $\mathrm{OH}$ & $\mathrm{H}$ \\
12 & $\mathrm{OH}$ & $\mathrm{OH}$ & $\mathrm{H}$ & $\mathrm{H}$ & $\mathrm{OH}$ & $\mathrm{H}$ & $\mathrm{H}$ & $\mathrm{OH}$ & $\mathrm{OH}$ \\
13 & $\mathrm{OH}$ & $\mathrm{OH}$ & $\mathrm{H}$ & $\mathrm{H}$ & $\mathrm{O}-\mathrm{\beta}-\mathrm{D}$-glucose & $\mathrm{H}$ & $\mathrm{OH}$ & $\mathrm{OH}$ & $\mathrm{H}$ \\
14 & $\mathrm{H}$ & $\mathrm{OH}$ & $\mathrm{H}$ & $\mathrm{OH}$ & $\mathrm{H}$ & $\mathrm{H}$ & $\mathrm{H}$ & $\mathrm{OH}$ & $\mathrm{H}$ \\
15 & $\mathrm{H}$ & $\mathrm{OH}$ & $\mathrm{H}$ & $\mathrm{H}$ & $\mathrm{OH}$ & $\mathrm{H}$ & $\mathrm{H}$ & $\mathrm{OH}$ & $\mathrm{OH}$ \\
16 & $\mathrm{OCH}_{3}$ & $\mathrm{OH}$ & $\mathrm{H}$ & $\mathrm{H}$ & $\mathrm{OCH}_{3}$ & $\mathrm{H}$ & $\mathrm{H}$ & $\mathrm{OCH}_{3}$ & $\mathrm{H}$ \\
17 & $\mathrm{OCH}_{3}$ & $\mathrm{OCH}_{3}$ & $\mathrm{OH}$ & $\mathrm{H}$ & $\mathrm{OCH}_{3}$ & $\mathrm{OH}$ & $\mathrm{H}$ & $\mathrm{OCH}_{3}$ & $\mathrm{OCH}_{3}$ \\
15 & $\mathrm{OCH}_{3}$ & $\mathrm{OCH}_{3}$ & $\mathrm{OCH}_{3}$ & $\mathrm{OCH}_{3}$ & $\mathrm{H}$ & $\mathrm{H}$ & $\mathrm{H}$ & $\mathrm{OCH}_{3}$ & $\mathrm{OCH}_{3}$ \\
19 & $\mathrm{OCH}_{3}$ & $\mathrm{OCH}_{3}$ & $\mathrm{OCH}_{3}$ & $\mathrm{OCH}_{3}$ & $\mathrm{H}$ & $\mathrm{H}$ & $\mathrm{H}$ & $\mathrm{OCH}_{3}$ & $\mathrm{H}$ \\
20 & $\mathrm{H}$ & $\mathrm{OH}$ & $\mathrm{H}$ & $\mathrm{H}$ & $\mathrm{OH}$ & $\mathrm{H}$ & $\mathrm{OH}$ & $\mathrm{OH}^{3}$ & $\mathrm{OH}$ \\
21 & $\mathrm{H}$ & $\mathrm{OH}$ & $\mathrm{H}$ & $\mathrm{H}$ & $\mathrm{O}-\mathrm{rutinoside}$ & $\mathrm{H}$ & $\mathrm{H}$ & $\mathrm{OH}_{3}$ & $\mathrm{OH}$ \\
22 & $\mathrm{H}$ & $\mathrm{O}$ & $\mathrm{H}$ & $\mathrm{H}$ & $\mathrm{H}$ & $\mathrm{H}$ & $\mathrm{H}$ & $\mathrm{OCH}$ & $\mathrm{H}$ \\
& & rutinoside & & & & & & & \\
23 & $\mathrm{H}$ & $\mathrm{OH}$ & $\mathrm{H}$ & $\mathrm{H}$ & $\mathrm{OH}$ & $\mathrm{H}$ & $\mathrm{H}$ & $\mathrm{OH}$ & $\mathrm{OCH}$ \\
24 & $\mathrm{H}$ & $\mathrm{OH}$ & $\mathrm{H}$ & $\mathrm{H}$ & $\mathrm{H}$ & $\mathrm{H}$ & $\mathrm{H}$ & $\mathrm{OH}$ & $\mathrm{OH}$ \\
\hline
\end{tabular}
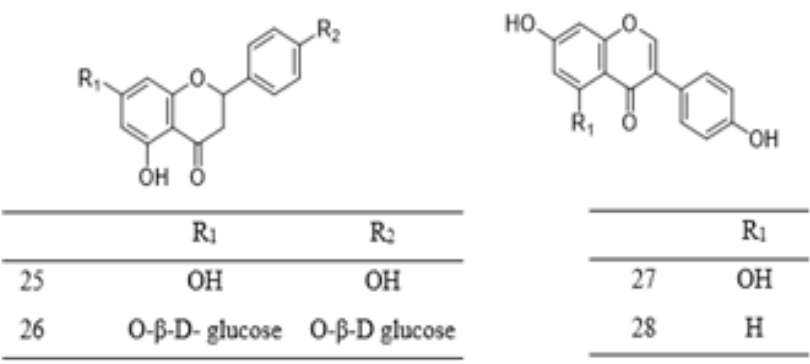

Figure 2. Structural formulas of polyphenolics $\mathbf{1 - 2 8}$, as previously listed in Table 2. 

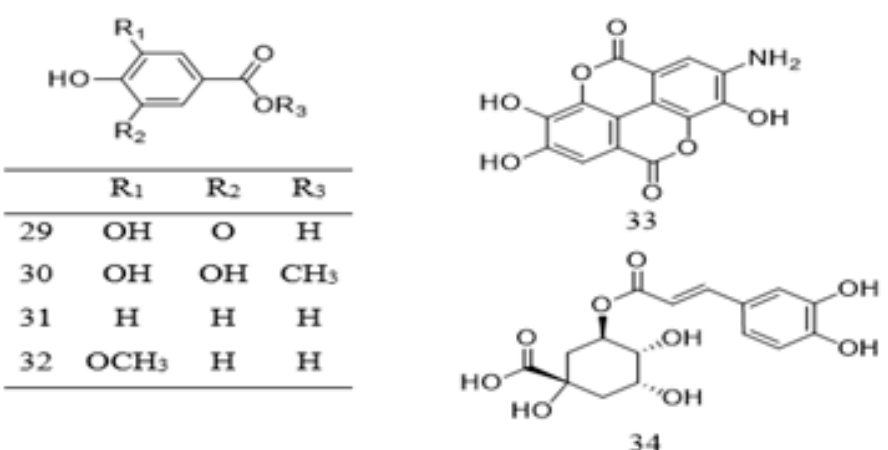

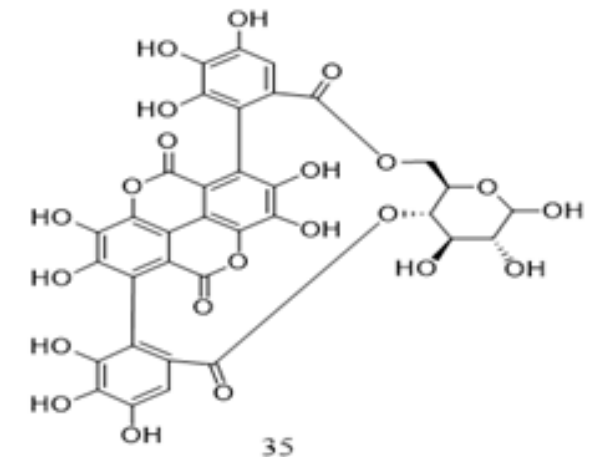

35<smiles>[R]c1ccc(/C=C/C(=O)O)cc1[R]</smiles><smiles>O=C(/C=C/c1ccccc1)OC(C(=O)O)[C@@H](O)C(=O)O</smiles>

40<smiles>O=C(/C=C/c1ccc(O)c(O)c1)O[C@H](C(=O)O)[C@@H](O)C(=O)O</smiles>

41<smiles>COc1cc(/C=C/C(=O)COCCCC(C)(C)C(=O)CCC(=O)OCC(O)CO)ccc1O</smiles>

42<smiles>CCCCC(C)(CC(C)(C)CC(=O)OCC(O)CO)C(=O)OCCOCC(=O)/C=C\c1ccc(O)c(OC)c1</smiles><smiles>[R10]c1cc2c(O)cc(O)cc2[o+]c1-c1cc(OC)c(O)c(OC)c1</smiles>

$\mathrm{HO}$<smiles>CCCCCCCCC(=O)OCc1ccccc1</smiles>

46

Figure 3. Structural formulas of polyphenolics 29-46, as previously listed in Table 2.

\subsection{Terpenoid and Steroid}

To date, few terpenoid compounds have been reported in Parkia plants. Most of these compounds were identified from barks, roots, leaves, and seeds of Parkia plants. One is monoterpenoid 50 with two of its glucosides 57 and 58 , a diterpene 49 , while the rest are triterpenoid 49 and 51-56 (Table 2 and Figure 4). Seven out of the triterpenoids 52-58 were reported as new compounds. Only 49 is reported in three species ( $P$. biglobosa, P. bicolor, and P. speciosa). Two of the new compounds 57 and 58 are iridoid type of terpenoidal glycoside purified from methanol extract of $P$. javanica, together with ursolic acid and other steroidal compounds [42]. Compounds 52-56 are isolated through different chromatographic techniques from $80 \%$ methanol extract of $P$. bicolor root, with a known diterpene 59 and a benzene glucoside 105. These compounds are reported to exhibit moderate antiproliferative activity with median inhibitory concentration $\left(\mathrm{IC}_{50}\right)$ ranging from $48.89 \pm 0.16$ to $81.66 \pm 0.17 \mu \mathrm{M}$ [118]. 


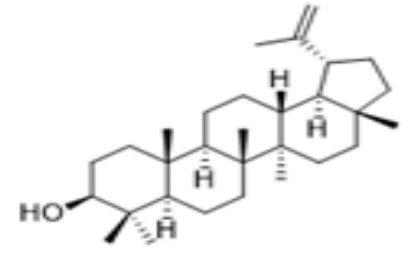

49<smiles>C=C(CC)C1CC=C(C)CC1</smiles>

so

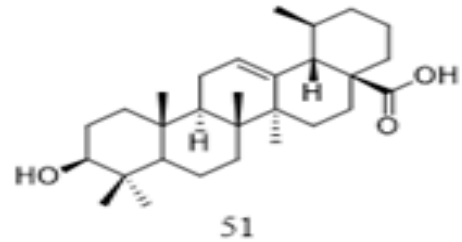

51

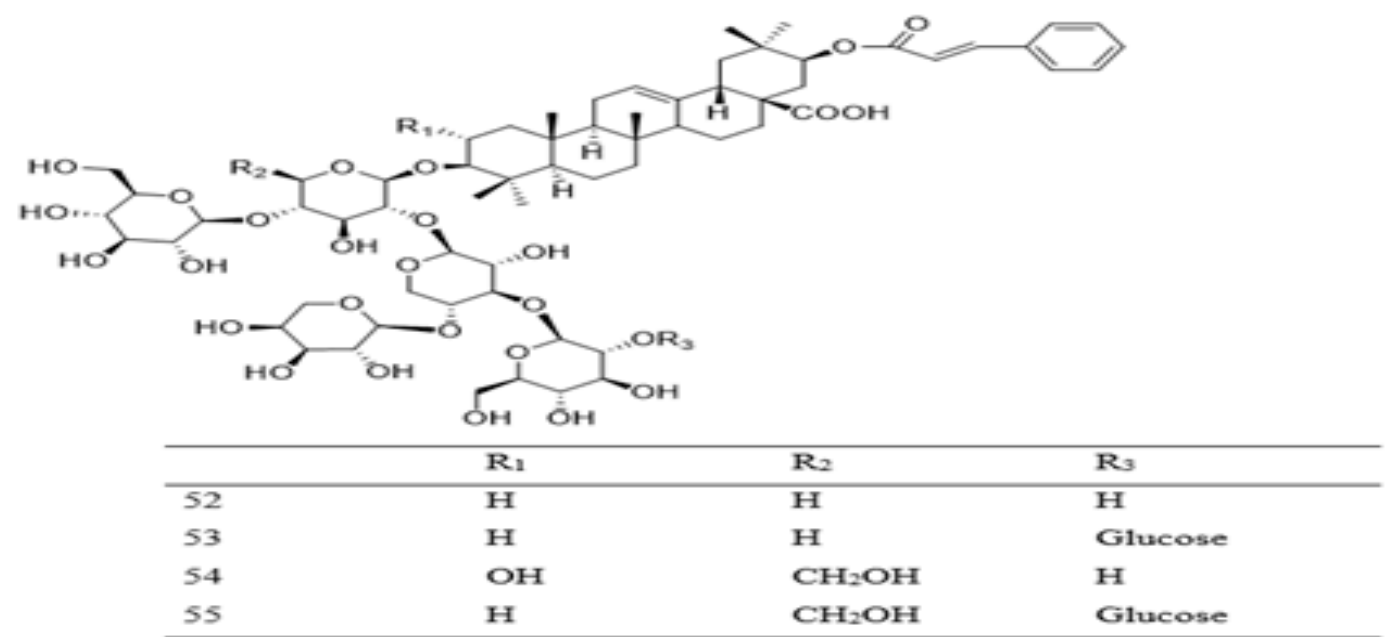

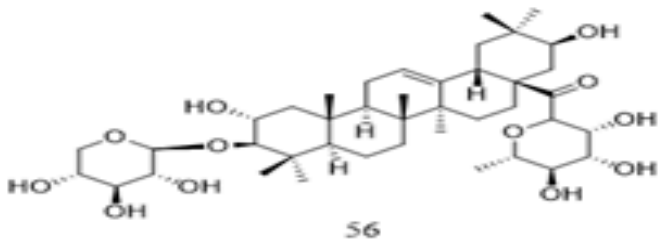

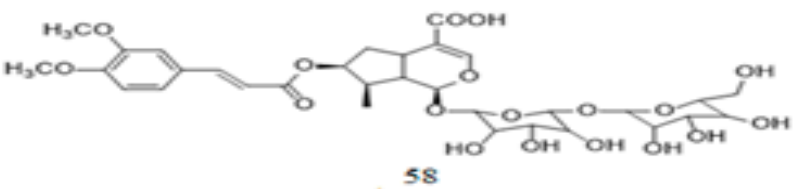

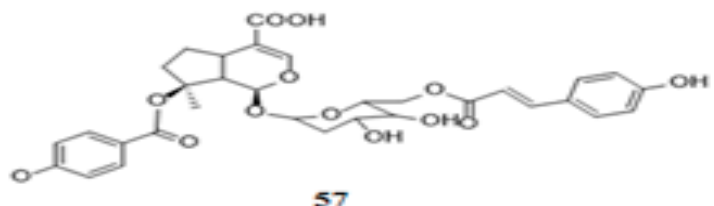

57
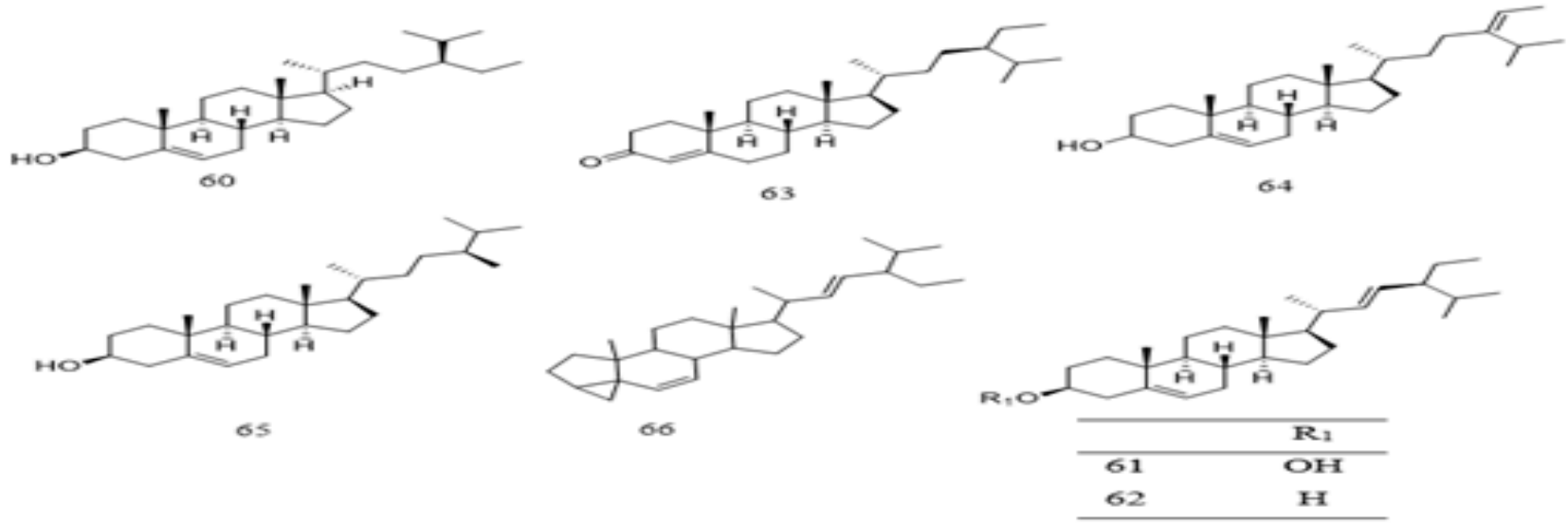

Figure 4. Structural formulas of terpenoids $49-59$ and steroids 60-66, as previously listed in Table 2. 
Steroidal compounds are also reported in the genus of Parkia (Table 2 and Figure 4). $\beta$ Sitosterol (60) is one of the major components in P. speciosa [120] and P. biglobosa seeds [121]. The steroid together with stigmasterol are purified from recrystallization of chloroform/ methanol fraction of $P$. speciosa seeds. Its composition in P. biglobosa seeds was reported to be about $377 \mathrm{mg} / 100 \mathrm{~g}$ dry weight [122]. It is also purified from methanol extract of $P$. javanica leaves [42]. Apart from 60, 61, and 65, which are present in P. javanica and/or P. biglobosa, all other steroids 62-64 and $\mathbf{6 6}$ reported from different studies are found in P. speciosa seeds. Other than $\beta$-sitosterol (60), stigmasterol (61), and campesterol (65) are also among the numerous compounds identified from the seeds of P. speciosa $[117,119,120,124]$. The percentage composition of $\mathbf{6 0}, \mathbf{6 1}, \mathbf{6 2}$ and a triterpenoid $\mathbf{4 9}$ in the plant was reported as $3.42 \%$, $2.18 \%, 2.29 \%$, and $0.71 \% w / w$, respectively [37]. In the case of P. biglobosa, the percentage composition of $\mathbf{6 0}, \mathbf{6 1}$ and $\mathbf{6 2}$ in the seeds is higher with values of $55.7 \%, 3.42 \%, 37.1 \%$ for the unfermented, and $56.8 \%, 3.38 \%, 35.9 \%$ for the fermented, respectively, indicating that fermentation process may lower $\mathbf{6 1}$ and $\mathbf{6 2}$, but increases $\mathbf{6 0}$ contents [129]. Meanwhile, Akintayo (2004) had recorded 60 as the most abundant compound in P. biglobosa seeds, constituting approximately $39.5 \% w / w$. Compound 60 was isolated as a pure compound through column chromatographic separation of benzene fraction of $P$. bicolor leaves [42].

\subsection{Miscellaneous Compounds}

In addition to polyphenolic and terpenoids, several other compounds that are mainly volatile including aldehydes, esters, pyrazines, ketones, fatty acids, benzenes, alcohols, amines, sulfides, alkanes, and alkenes have been reported from Parkia species (Table 2). These compounds are identified mainly from the seeds. Compound $\mathbf{8 1}$ is identified from the natural product for the first time in pentane/dichloromethane fraction of $P$. speciosa seed using GC/ToF-MS [125]. A greater number of these compounds is identified through phytochemical quantification using different spectroscopic methods. Seven constituents are detected from the fresh seeds of $P$. speciosa through GC/ToF/MS and the compounds are dominated by linear polysulfide, alcohol, and $3^{\prime}$-thiobis-didodecyl ester. Other major compounds include palmitic acid, arachidonic acid, linoleic acid, linoleic acid chloride, and myristic acid [124]. However, cyclic polysulfides are the major constituents found in cooked P. speciosa seeds (Figure 5) [125]. In addition, some minor components, such as 82-84 are also identified. Meanwhile, $\mathbf{1 3 2}$ content in P. speciosa seed was reported to be $4.15 \mathrm{mg} / 100 \mathrm{~g}$ [37], but that of P. biglobosa in a recent study was found to be much higher (53.47 mg/100 g). Phospholipid content of P. biglobosa seeds was about $451 \mathrm{mg} / 100 \mathrm{~g}$ [122]. The seeds also contain palmitic acid, stearic acid, oleic acid, arachidic acid, and linoleic acid, the most abundant fatty acid $[22,121,130]$. Similar fatty acids are also reported in the raw seeds of $P$. roxburghii chloroform/methanol extract, in addition to total free phenol $(0.56 \mathrm{~g} / 100 \mathrm{~g}$ seed flour $)$ and tannins $(0.26 \mathrm{~g} / 100 \mathrm{~g}$ seed flour) contents [41].

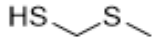

81

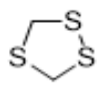

85<smiles>C1CSCCSSC1</smiles>

89

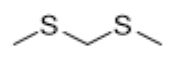

82<smiles>C1SCSCS1</smiles>

86

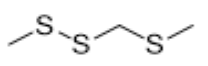

83

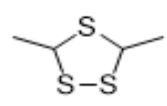

87

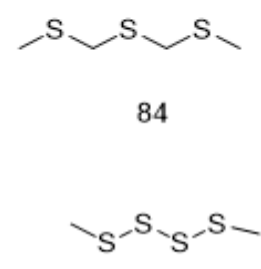

88

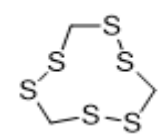

93

Figure 5. Structural formulas of cyclic polysulfides 81-93, as previously listed in Table 2. 


\section{Pharmacological Activities of Parkia Species}

Numerous bioactive constituents such as phenolics, flavonoids, terpenoids, and volatile compounds present in Parkia species may account for its various health benefits, and therefore responsible for the vast pharmacological properties (Table 3). However, only few species have been extensively studied.

\subsection{Antimicrobial Activity}

Various parts of many species of Parkia have good antimicrobial activities. They are most active against $S$. aureus and E. coli (Table 3). So far, there is still no clinical study conducted on the plants investigating the activity. Enormous reports have been made on antimicrobial activity of different parts of P. biglobosa such as leaves [23,65,131-135], stem barks $[31,43,45,65,67,131,134-137]$, seeds [138], roots [34,38,139] and pods [133,140]. Furthermore, the stem barks and leaves of $P$. clappertoniana aqueous and methanol extracts investigated on some Gram-positive and Gram-negative bacteria revealed that both stem barks and leaves were effective in all tested organisms, but methanol extract was more potent [71]. The ethanol extract of both leaves and barks demonstrated growth inhibitory effects on multi-drug resistant Salmonella and Shigella isolates [73]. The ethanol extract of P. platycephala seeds tested against six bacteria strains and three yeasts showed no antimicrobial activity [141]. However, lectin obtained from the seed was reported to significantly enhance antibiotic activity of gentamicin against $S$. aureus and E. coli multiresistant strains due to interaction between carbohydrate-binding site of the lectin and the antibiotic [142].

In P. speciosa, the water suspension of the seeds displays some remarkable inhibitory activity against bacteria isolated from the moribund fishes and shrimps-S. aureus, A. hydrophila, S. agalactiae, S. anginosus and V. parahaemolyticus-but no detectable activity against E. coli, V. alginolyticus, E. tarda, C. freundii, and V. vulnificus [143]. The methanol, chloroform, and petroleum ether extracts of the seeds demonstrate growth inhibitory effect against $H$. pylori [144], while the ethyl acetate extract against $E$. coli, but no effect on $S$. typhi, S. sonnei, and S. typhimurium [144]. The antimicrobial activity of P. speciosa is attributable to the presence of cyclic polysulfides 85 and 92-94 in the seeds [126]. However, possible mechanism of the polysulfides was not elucidated. Both pod extract and its synthesized silver nanoparticles exhibit antibacterial activity, with the latter shows higher activity against $P$. aeruginosa [145]. A similar antibacterial activity is also seen with aqueous extract of $P$. speciosa leaves and its silver nanoparticles against $S$. aureus, B. subtilis, E. coli, and P. aeruginosa [146]. Its bark methanol extract inhibits the growth of Gloeophyllum trabeum, but not Pycnoporus sanguineus, which effect is not seen with both sapwood and heartwood of the plant [147]. Its ethyl acetate extract of the peel also shows four times higher activity against $S$. aureus and three times higher against $E$. coli than streptomycin, but n-hexane extract exhibits lower activity [148].

Various parts of P. timoriana inhibit growth of B. cereus, V. cholerae, E. coli, and $S$. aureus [149]. Its leaf extract exhibits significant growth inhibitory effect against $E$. coli, $V$. cholerae, S. aureus, and B. cereus [150], while its gold and silver nanoparticles from dried leaves inhibit $S$. aureus growth. The activity is believed to be attributable to the accumulation and absorption of the gold and silver nanoparticles into S. aureus cell wall [151]. The methanol extract and semi-polar fractions (chloroform and ethyl acetate) of the bark demonstrate significant inhibitory effects against Neisseria gonorrhoeae. The chloroform extract shows the best activity [97]. The aqueous extract of the seed, leaf and skin pod also possess antimicrobial activity [152].

Acetone, ethanol and aqueous extracts of P. biglandulosa stem bark were among the plant extracts that show the highest antimicrobial activity against bacteria and fungi [69] as well as plant pathogenic bacteria [153]. The methanol extract of the leaves also shows remarkable growth inhibition against E. coli, P. aeruginosa, and S. aureus [154]. Investigation on P. bicolor indicates that ethyl acetate, ethanol, and aqueous extracts of the leaves demonstrate a concentration-dependent growth inhibitory effect against some Gram-positive of 
bacteria such as E. coli, S. aureus, P. aeruginosa, A. niger, B. cereus, and a fungus, C. utilis [23]. Methanol, ethyl acetate, and water extracts of the root also exhibit different degrees of inhibition against some common human pathogenic bacteria including C. diphtheriae, K. pneumoniae, P. mirabilis, S. typhi, and S. pyogenes [28]. The possible mechanism of the antimicrobial activity of Parkia plants are yet to be determined. However, terpenoids from the plants could induce lipid flippase activity in the bacterial cellular membrane which then enhances membrane damage for a better cell penetration [155]. Other possible actions could be by damaging bacterial protein, inhibiting DNA gyrase and DNA synthesis, which are yet to be confirmed in further studies.

Collectively, it can be concluded that the antimicrobial properties of Parkia plants depend on the species and parts of Parkia as well as solvent (polar and non-polar). Most of the published report are in in vitro evaluations, which do not assure the same outcomes in animal models and clinical setting. In the rise of resistant pathogenic bacteria to antimicrobial therapy, it is an urgent need to develop new antimicrobial agents, and phytoconstituents from plants like Parkia could be good candidates.

\subsection{Antidiabetic Activity}

P. speciosa is the most studied among other species for antidiabetic activity. Six studies comprising three in vitro and three in vivo studies have demonstrated hypoglycemic activity of the plant, but no clinical study has been conducted. Most of the studies have studied the activity in the seeds and pods [120,156-158].

Pericarps from $P$. speciosa show significant inhibitory activity $\left(\mathrm{IC}_{50} 0.0581 \mathrm{mg} / \mathrm{mL}\right.$; $89.46 \%$ ) against $\alpha$-glucosidase [156], an enzyme responsible for breaking down starch and polysaccharide into glucose [159]. The seeds also show inhibitory activity but at lower percentage (45.72\%) [156]. In another study, the ethanol extract of the rind had the highest $\alpha$-glucosidase inhibitory activity followed by the leaf and seed with $\mathrm{IC}_{50}$ of 4596 ppm, 54,341 ppm, and 67,425 ppm, respectively as compared with acarbose having 162,508 ppm [158].

An in vivo study conducted on both seeds and pods of $P$. speciosa in alloxan-induced diabetic rats, indicated that only chloroform extract of both pods and seeds exhibited strong glucose-lowering activity. The hypoglycemic activity of the seeds was higher than that of the pods (57\% and 36\%, respectively) [157]. A mixture of $66 \% \beta$-sitosterol 60 and $34 \%$ stigmasterol $\mathbf{6 1}$ is believed to be responsible for the hypoglycemic effect of the seedsdemonstrated $83 \%$ decrease in blood glucose level $(100 \mathrm{mg} / \mathrm{kg}$ body weight) compared to glibenclamide (111\% at $5 \mathrm{mg} / \mathrm{kg}$ bw) [120]. Similarly, stigmast-4-en-3-one 63 was identified as the compound responsible for the $84 \%$ reduction in blood glucose level at $100 \mathrm{mg} / \mathrm{kg}$ bw of the pod extract of P. speciosa [123]. Both compounds ( $\beta$-sitosterol and stigmasterol) are believed to reduce blood glucose level by regenerating remnant $\beta$-cells and stimulating insulin release [160] via augmentation of GLUT4 glucose transporter expression [161]. Stigmasterol is also reported to inhibit the ß-cells apoptosis [162].

In other Parkia species, methanol crude extracts and fractions of $P$. timoriana pods showed significant $\alpha$-glucosidase and $\alpha$-amylase inhibitory activities in streptozotocininduced diabetic rats. Ethyl acetate fraction had the highest $\alpha$-glucosidase inhibitory and moderate $\alpha$-amylase inhibitory activities, with maximal reduction in blood glucose level back to normal observed on day 14 at the dose of $100 \mathrm{mg} / \mathrm{kg}$ body weight [18]. $\alpha$-Amylase functions to hydrolyze starch into maltose and glucose [163]. Bioassay-guided chemical investigation of the most active ethyl acetate fraction revealed epigallocatechin gallate 4 and apigenin 14 were responsible for the antidiabetic activity [18].

Oral administration of $P$. biglobosa methanol and aqueous extracts of fermented seeds exhibited different degrees of hypoglycemic effects on fasting plasma glucose when tested on alloxan-induced diabetic rats after four weeks $[164,165]$. Oral administration of P. biglobosa seeds methanol extract $(1 \mathrm{~g} / \mathrm{kg}$ body weight) lowered blood glucose level by $44.1 \%$ at $8 \mathrm{~h}$ as compared with glibenclamide (37.9\%) in alloxan-induced diabetic rats. Its chloroform fraction exerted maximum glucose-lowering effect $(65.7 \%)$, while n-hexane fraction had 
the lowest (4.7\%) [39]. As previously mentioned, similar underlying mechanism of the hypoglycemic activity of the plant species is suggested which is via an improvement in pancreatic islet functions to release insulin, while abolishing insulin resistance [166]. For future study directions, investigations on the effects of the plant extracts and pure compounds on insulin release and signaling pathways that might be involved in the glucose-lowering properties could be conducted. The compounds should also be studied clinically.

\subsection{Anticancer Activity}

Cancer is one of the diseases that cause death of millions worldwide. Dietary intake of raw seeds was also reported to significantly lower the occurrence of esophageal cancer in southern Thailand [167]. The methanol extract of $P$. speciosa seeds exhibited a moderate antimutagenic activity in the Ames test [168], but weak activity in Epstein-Barr virus inhibitory assay [169]. The methanol extract of the seed coats demonstrated selective cytotoxicity against MCG-7 and T47D (breast cancer), HCT-116 (colon cancer) and HepG2 (hepatocarcinoma) cells, while its ethyl acetate fraction only showed selective cytotoxicity against MCF-7, breast cancer cells [170].

Substances that enhance mitogenesis of lymphocytes may be useful as antitumor or antiproliferative and immunomodulator agents [171]. Lectin obtained from the P. speciosa seeds exerted mitogenic activity in both rat thymocytes and human lymphocytes by stimulating the incorporation of thymidine into DNA cell, which activity was comparable to the known T-cell mitogens like pokeweed mitogen, concanavalin A and phytohemagglutinin [6,172]. Lectins isolated from the seeds of P. biglandulosa and P. roxburghii have demonstrated antiproliferative effect on murine macrophage cancer cell lines-P 388DI and J774. The seed extract $P$. roxburghii also inhibits the proliferation of B-cell hybridoma cell line, HB98 [173], and HepG2 cells without affecting the normal cells [44]. The monosaccharide saponins 52-55 isolated from P. bicolor root also exhibit moderate antiproliferative effect $\mathrm{IC}_{50}$ ranging from 48.49 to $81.66 \mu \mathrm{M}$ [118]. To our knowledge, the anticancer effects of Parkia extracts were only investigated in cell lines-limited to cell growth inhibition-not yet studied in in vivo models.

An in vitro study on human cancer cell lines has shown that the methanol extracts of P. biglobosa and P. filicoidea exhibit different degrees of antiproliferative activities on T-549 and BT-20 (prostate cancer), PC-3 (acute T cell leukemia Jurka), and SW-480 (colon cancer) at concentrations of 20 and $200 \mu \mathrm{g} / \mathrm{mL}$. P. biglobosa also exhibits higher cytotoxic activity against all types of cancer cell lines used compared with P. filicoidea [174]. The antitumor property could be attributable to the antiangiogenic activity of some species of Parkia such as P. biglandulosa and P. speciosa extracts $[170,175]$. Angiogenesis or neovascularization is involved in metastasis of solid tumors. Methanol extract of the P. speciosa fresh pods was reported to exhibit antiangiogenic activity by more than $50 \%$ inhibition of microvessel outgrowth in rat aortae and human umbilical vein endothelial cells forming capillary-like structures in Matrigel matrix. The effect may be attributable to the ability of the compounds in the extract to form vacuoles in the cells [170], which is essential in maintaining the viability of the cells, therefore beneficial in the treatment of cancer owing to its capacity to prevent tumor neovascularization [176].

The plant bioactive compounds could also possibly increase apoptotic signaling pathway by elevating caspase activation as similarly shown by the same compounds in other plant species [177], as well as a direct inhibition on DNA synthesis, related to the ability to inhibit the expressions of several tumor- and angiogenesis-associated genes. Future studies should explore on the possible mechanism of action that are responsible for the anticancer activity. Additionally, future research on human studies is needed to confirm the outcomes seen in the laboratories.

\subsection{Antihypertensive Activity}

Antihypertensive activity of $P$. biglobosa seeds has been demonstrated in both animals and human. Only a clinical study was conducted which observed lower blood pressure, 
blood glucose and heart rate, high level of magnesium as well as improved lipid profile in patients with hypertension consuming fermented seeds of $P$. biglobosa in comparison with the non-consumption group [178]. Administration of $1.9 \mathrm{mg} / \mathrm{mL}$ of seed extract of P. biglobosa lowers the arterial blood pressure level in a rat model, possibly due to its ability to slow down the heart rate [179] and to induce vascular relaxation [180]. The latter effect is also seen with roasted seeds of the plant [180]. Other than the seeds, P. biglobosa stem bark aqueous extract also demonstrates good hypotensive effect in adrenaline-induced hypertensive female rabbits, which effect is comparable to antihypertensive drugs, propranolol and nifedipine [181]. The hypotensive properties of $P$. biglobosa could be owing to its main phytochemicals-phenolics and flavonoids. Catechin and its derivatives are among the most common compounds detected in the plant. These compounds promote vasorelaxation [182] by modulating nitric oxide availability [183] and inhibiting angiotensinconverting enzyme (ACE) [184], in addition to a reduction in oxidative stress [185], leading to blood pressure-lowering effects of the plant extract. The fermented seeds also decrease plasma triglyceride and cholesterol levels in Tyloxapol-induced hyperlipidemic rats [186], and platelet aggregation [187].

P. speciosa empty pod extract has been reported to prevent the development of hypertension in rats given L-NG-nitroarginine methyl ester (L-NAME), a nitric oxide synthase inhibitor, possibly due to its ability to prevent nitric oxide loss [122], which is dependent on the availability of endothelial nitric oxide synthase [188], as well as to inhibit ACE and oxidative stress and inflammation [112]. Both oxidative stress and inflammation are known to play important roles in the pathogenesis of hypertension (Siti et al. 2015). Active peptide obtained from hydrolyzed P. speciosa seeds displays ACE-inhibitory effect, ranging from $50.6 \%$ to $80.2 \%$, which effect is not observed in the non-hydrolyzed seeds, possibly due its long and bulky structure $[189,190]$. However, the study of Khalid and Babji $(2018)$ has demonstrated that the aqueous extract of the seeds also possesses ACE inhibitory activity [191]. These studies suggest that the blood pressure-lowering effect of the P. speciosa is most likely due to its ACE inhibitory property and nitric oxide regulation, attributable to its rich contents of polyphenols and the presence of peptide. Future studies should involve isolation of the active compounds which have a potential to be developed as a specific inhibitor of ACE. Other possible mechanisms-specific receptor antagonism, such as adrenoceptors and calcium channels, or modification of signaling pathways—of blood pressure-lowering effects of the plant extract or compounds should be explored further.

\subsection{Antidiarrheal Activity}

The antidiarrheal effect of Parkia plants has been investigated using many models such as castor oil- and magnesium-induced diarrhea. The aqueous extract of $P$. filicoidea stem barks reduces the frequency of stooling in rats with castor oil-induced diarrhea, comparable with loperamide [192]. The aqueous and ethanol extract of $P$. biglobosa leaves and stem barks also exhibit similar antidiarrheal activity to loperamide, seen as a reduction in stooling frequency and intestinal volume $[45,59,193]$. These effects could be attributable to its inhibitory capacity on the propulsive movement of gastrointestinal tract smooth muscles [45]. Medicinal plants are believed to exert antidiarrheal activity by enhancing the opening of intestinal potassium channel and stimulating $\mathrm{Na}^{+} / \mathrm{K}^{+}$-ATPase activity, as well as decreasing intracellular calcium concentration, which then promotes gastrointestinal smooth muscle relaxation, leading to diminished diarrhea [194-196]. The potential of these plants as agents to reduce diarrhea can be explored further in irritable bowel syndrome or chemotherapy-induced diarrhea. Their effects on intestinal mucosal barrier, tight junction proteins and inflammatory cytokines among others can be examined.

\subsection{Antiulcer Activity}

The gastroprotective effect of Parkia plants was seen in three species which were P. speciosa, P. platycephala and P. biglandulosa (Table 3). The leaves and seeds of P. speciosa protected against ethanol- and indomethacin-induced gastric ulcer in rats, observed by 
reductions in the gastric ulcer index and acidity of gastric juice $[197,198]$. Lesser collagen and fibrotic ulcer were significantly diminished in the extract-treated group [197]. The ethanol extract of $P$. platycephala also showed protective effect in gastric mucosal injury models induced by ethanol, ischemia-reperfusion, and ethanol-HCl. However, the extract could not protect against indomethacin-induced gastric lesion [199]. These plants are rich in flavonoids. The compounds like catechin and quercetin confer antiulcer effects possibly by eradicating the formation of ROS and modulating mucin metabolism in the gastrointestinal tract [200-202]. Other possible protective mechanisms could be by reducing gastric acid secretion, thereby decreasing gastric acid $\mathrm{pH}$, as seen with cinnamic caffeic, $\mathrm{p}$-coumaric or ferulic acids-the compounds that are present in the plants [203]. Studies on other possible effects of the extracts or bioactive components such as proton pump inhibition could be of interest. In future, the compounds that are responsible for the protective effects should be identified and the possible protective signaling mechanisms should be elucidated. Moreover, clinical trials can be performed to assess the potential use of Parkia extracts as an antiulcer agent.

\subsection{Antianemic Activity}

The fermented seeds of P. biglobosa are a rich source of essential minerals such as iron, calcium, thiamine, and phosphorus [57] which are necessary in forestalling either iron or non-iron deficiency anemia. Therefore, the antianemic capacity of $P$. biglobosa could be owing to its nutritional composition. The fermented seeds of P. biglobosa in combination with other fermented products were reported to be beneficial in the management of anemia as it increased hemoglobin, red blood cells, white blood cells, and packed cell volume [204]. The ethanol extract of $P$. speciosa seeds were also investigated in $\mathrm{NaNO}_{2}$-induced anemic mice. At doses of 400 and $700 \mathrm{mg} / \mathrm{kg}$, an elevation of hemoglobin levels was noted to 0.92 and $0.82 \mathrm{~g} / \mathrm{dL}$, respectively [205]. The exact mechanism of how P. speciosa acts to decrease anemia is still unclear. It could be due to its rich source of the minerals, particularly the iron [171]. Another possible mechanism would be stimulation of erythropoiesis process. Both extracts of P. biglobosa P. biglobosa and P. speciosa can be developed as an alternative iron supplement. However, the effectiveness should be evaluated clinically.

\subsection{Anti-Inflammatory Activity}

Inflammatory reaction is involved in almost all clinical manifestation. Hence, antiinflammatory activity of certain plant extracts could be of benefit. Anti-inflammatory activity of P. biglobosa stalk [206], seeds and stem bark [29], P. speciosa pods [187,188] and seeds [84], as well as P. platycephala seeds [207] have been reported using various models of inflammation.

The protective effects of P. biglobosa is believed via its inhibitions on the lipoxygenase and cyclooxygenase pathways [206], leading to inhibition of pro-inflammatory cytokine release and stimulation of anti-inflammatory cytokine [208], as well as increment on membrane stabilization [209]. While the P. speciosa exerts its anti-inflammatory by downregulating nuclear factor kappa $B$ cell (NF- $\mathrm{KB}$ ) and p38 mitogen-activated protein kinase (MAPK) pathways $[187,188]$. It is obvious that the plant bioactive components attenuate inflammation by regulating inflammatory and MAPK signaling pathways, which could lead to reduced formation of inflammatory mediators such as cytokines. To date, no study has identified the anti-inflammatory compounds from Parkia, which warrants further studies on this aspect, either in experimental animals or human studies.

\subsection{Antioxidant Activity}

Polyphenolic compounds present in plant foods have been reported to be responsible for their antioxidant activity due to their ability to serve as a hydrogen donor and reducing agent (Amorati and Valgimigli 2012). Both fermented and unfermented seeds of P. biglobosa

have been reported to contain an appreciable amount of phenolic contents $[210,211]$. P. timoriana pods are also rich in total phenolic and flavonoid contents [212]. The antioxidant 
capacity of the leaves and seeds of $P$. speciosa has been reported to be relatively lower than that of the empty pods and seed mixture, suggesting that the pods possess higher antioxidant contents than other parts of the plant $[37,176]$. The difference in geographical location may affect the composition of the antioxidant compounds in plants. It was reported that $P$. speciosa seeds collected from central Peninsular Malaysia had higher antioxidant capacity than the southern and southwestern regions [213]. The compounds present in the plants attenuate oxidative stress possibly by activating Nrf2/Keap1 and MAPK signaling pathways, leading to enhanced expressions of Nrf2 and antioxidant enzymes, such as heme oxygenase-1 [214]. P. speciosa extracts of seed coats and pods could also reduce the risk of hemolysis by inhibiting Heinz body production in the erythrocytes incubated with a hemolytic agent [215], indicating the ability of the extracts to inhibit oxidative destruction of erythrocyte. The finding suggests a potential of the plant extract to reduce hemolytic jaundice, which warrants further research.

\subsection{Other Pharmacological Activities}

Other than previously mentioned activities, the P. biglobosa extract has also been demonstrated to have antimalarial effect [11], whereas P. clappertoniana [75] and P. biglobosa [216] show nephro- and hepatoprotective effects, respectively (Table 3). P. pendula seeds also enhance wound healing in immunosuppressed mice [217]. However, extensive studies regarding these effects were not performed. Further studies need to be conducted to explore the possible mechanisms that are involved in the aforementioned beneficial effects.

\section{Toxicity}

Daily consumption of cooked pods of $P$. roxburghii does not impose any significant adverse effect [218]. However, eating raw pods may result in bad breath owing to its rich content in volatile disulfide compounds, which are exhaled in breath and the odor can persist for several hours (Meyer, 1987). Many substances have been identified or isolated from Parkia seed, such as lectins, non-protein amino acids, and alkaloids [219]. However, no acute mortality and observable behavioral change were recorded at doses up to $2000 \mathrm{mg} / \mathrm{kg}$ ethyl acetate fraction of $P$. roxburghii pod in rats [18]. Investigation on acute and sub-acute toxicity profiles of the aqueous and ethanol extracts of the stem bark of P. biglobosa showed that the oral median lethal dose $\left(L_{50}\right)$ was higher than $5000 \mathrm{mg} / \mathrm{kg}$ for both extracts in rats [36]. However, in another report, $\mathrm{LD}_{50}$ values of the leaves, stems and roots in an acute toxicity study were within the range of $500-5000 \mathrm{mg} / \mathrm{kg}$ body weight of fish, suggesting that they are only slightly toxic and, therefore, not potentially dangerous. The adverse effects included respiratory distress and agitated behavior [220]. Apart from the barks of $P$. biglobosa, the pods also possess the piscicidal activity that can be used in the management and control of fishponds to eliminate predators [220,221]. Fatty acids and oils identified from the seeds of P. biglobosa and P. bicolor were reported to be non-toxic [22].

The aqueous extract of $P$. clappertoniana seeds showed no observable maternal and developmental toxicity at $100-500 \mathrm{mg} / \mathrm{kg}$ when given orally to Sprague-Dawley rats and mice at different gestational age ([17]. P. platycephala leaves at $1000 \mathrm{mg} / \mathrm{kg}$ on the other hand, caused decreases in body mass, food and water consumption in rats. It also shortened the proestrus and prolonged diestrus phases, as well as reduced uterine weight, suggestive of possible alterations on hormonal levels, but no obvious toxicity on other organs [53]. Oral administration of the leaves of P. speciosa for 14 days showed no significant histopathological toxicity or mortality in rats at up to $5000 \mathrm{mg} / \mathrm{kg}$ [198]. In vitro, the plant pods $(100 \mu \mathrm{g} / \mathrm{mL})$ showed no significant cytotoxic effect on normal cell lines [170]. Consumption of the seeds up to 30 pieces in a serve does not produce any adverse effects [176]. 
Table 3. Pharmacological activities of Parkia species extracts and fractions.

\begin{tabular}{|c|c|c|c|c|c|}
\hline Activity & Species & Part & Type of Extract/Compound & Key Findings & References \\
\hline \multirow{10}{*}{ Antimicrobial } & P. biglobosa & Leaf, stem bark, and root & Methanolic and aqueous & $\begin{array}{c}\text { Active against } S \text {. aureus, B. subtilis, E. coli, } \\
\text { P. aeruginosa. }\end{array}$ & [38] \\
\hline & P. biglobosa & Root bark & Aqueous and methanol & $\begin{array}{c}\text { Active against E. coli, S. aureus, K. pneumoniae, } \\
\text { P. aeruginosa. } \\
\text { Activity: Aqueous }>\text { methanol }\end{array}$ & {$[34]$} \\
\hline & P. biglobosa & Leaves and pod & Aqueous and ethanol & $\begin{array}{c}\text { Active against S. aureus, E. aerogenes, S. typi, } \\
\text { S. typhimurium, Shigella spp., E. coli, and } \\
\text { P. aeruginosa (bacteria), Mucor spp., and } \\
\text { Rhizopus spp. (fungi) }\end{array}$ & [133] \\
\hline & P. biglobosa & Bark and leaves & Hydro-alcohol and aqueous & $\begin{array}{l}\text { Active against E. coli, S. enterica, and S. dysenteriae. } \\
\text { Activity: hydroalcoholic }>\text { aqueous }\end{array}$ & [65] \\
\hline & P. speciosa & Seeds & Water suspension & $\begin{array}{l}\text { Active against S. aureus, A. hydrophila, S. agalactiae, } \\
\text { S. anginosus, and V. parahaemolyticus isolated from } \\
\text { moribund fishes and shrimps }\end{array}$ & [143] \\
\hline & P. speciosa & Seed peel & $\begin{array}{l}\text { Ethyl acetate (EA) Hexane } \\
\text { Ethanol }\end{array}$ & $\begin{array}{l}\text { EA: Four times higher than streptomycin against } \\
\text { S. aureus and three times higher for E. coli. } \\
\text { Hexane: } 50 \% \text { inhibitory ability of streptomycin for } \\
\text { both bacteria. Ethanol: no inhibition }\end{array}$ & [148] \\
\hline & P. speciosa & Pod extract and its silver & Aqueous & $\begin{array}{c}\text { Pod: active against } P \text {. aeruginosa Silver particles: } \\
\text { active against } P \text {. aeruginosa }\end{array}$ & [145] \\
\hline & P. speciosa & Sapwood, heartwood, and bark & Methanol & $\begin{array}{c}\text { Bark: Active against G. trabeum. Sapwood and } \\
\text { heartwood: No effect }\end{array}$ & [147] \\
\hline & P. speciosa & Seeds & $\begin{array}{l}\text { Chloroform, petroleum ether, Aqueous } \\
\text { and methanol }\end{array}$ & $\begin{array}{c}\text { Active against } H \text {. pylori except aqueous extract. } \\
\text { Activity: chloroform }>\text { methanol }>\text { petroleum } \\
\text { ether }\end{array}$ & [222] \\
\hline & P. speciosa & Seed & $\begin{array}{l}\text { Methanol } \\
\text { Ethyl acetate }\end{array}$ & $\begin{array}{l}\text { Methanol: active against } H \text {. pylori. Ethyl acetate: } \\
\text { active against E. coli } \\
\text { Both: no effect on } S \text {. typhimurium, S. typhi, and } \\
\text { S sonnei }\end{array}$ & [144] \\
\hline
\end{tabular}


Table 3. Cont

\begin{tabular}{|c|c|c|c|c|c|}
\hline Activity & Species & Part & Type of Extract/Compound & Key Findings & References \\
\hline & P. javanica & Stem bark & Methanol & $\begin{array}{l}\text { Good inhibitory activity against E. coli, S. aureus } \\
\text { S. pyogenes found in chronic wound }\end{array}$ & [223] \\
\hline & P. javanica & Stem bark & Methanol & Active against four Vibrio cholerae strains & [224] \\
\hline & P. javanica & Leaves & Gold and silver nanoparticles & Good inhibitory activity against S. aureus & [151] \\
\hline & P. javanica & Bark & $\begin{array}{l}\text { Methanol extract and semi-polar } \\
\text { fractions (chloroform and ethyl acetate) }\end{array}$ & $\begin{array}{c}\text { Active against Neisseria gonorrhoeae. Chloroform } \\
\text { showed the best activity }\end{array}$ & [97] \\
\hline & P. javanica & Seeds, leaves and skin pods & Aqueous & $\begin{array}{l}\text { Active against } S \text {. aureus, A. hydrophila, and } \\
\text { S. typhimurium Not active against } E \text {. coli }\end{array}$ & [152] \\
\hline & P. clappertoniana & Leaves and barks & Ethanol & Active against Salmonellae and Shigella & [73] \\
\hline & P. clappertoniana & Stem bark and leaves & Aqueous and methanol & $\begin{array}{l}\text { Active against } S \text {. aureus and P. aeruginosa. } \\
\text { Methanol extract was more potent }\end{array}$ & [71] \\
\hline & P. biglandulosa & Leaf & Methanol & Active against E. coli, P. aeruginosa, and S. aureus & [154] \\
\hline & P. filicoidea & Stem barks & Aqueous, acetone and ethanol & $\begin{array}{l}\text { Active against } S \text {. aureus, K. pneumoniae, } \\
\text { P. aeruginosa, S. viridans and B. subtilis. Not active } \\
\text { against E. coli }\end{array}$ & [50] \\
\hline & P. bicolor & Roots & Methanol, ethyl acetate and Aqueous & $\begin{array}{l}\text { Active against } C \text {. diphtheria, K. pneumoniae, } \\
\text { P. mirabilis, S. typhi, and S. pyogenes }\end{array}$ & [28] \\
\hline & P. pendula & Seeds & Lectin & $\begin{array}{c}\text { Reduced cellular infectivity of human } \\
\text { cytomegalovirus in human embryo lung } \\
\text { (HEL) cells. }\end{array}$ & [225] \\
\hline \multirow{2}{*}{ Hypoglycemic } & P. speciosa & Seeds and pods & Chloroform & $\begin{array}{l}\text { Strong glucose-lowering activity in } \\
\text { alloxan-induced diabetic rats } \\
\text { Activity: seeds > pod }\end{array}$ & [157] \\
\hline & P. speciosa & Rind, leaves and seeds & Ethanol & $\begin{array}{l}\text { Inhibited } \alpha \text {-glucosidase activity in rat } \\
\text { Activity: rind }>\text { leaf }>\text { seed }\end{array}$ & [158] \\
\hline
\end{tabular}


Table 3. Cont.

\begin{tabular}{|c|c|c|c|c|c|}
\hline Activity & Species & Part & Type of Extract/Compound & Key Findings & References \\
\hline & P. speciosa & Seed & Chloroform & $\begin{array}{l}\text { Reduced plasma glucose levels in alloxan-induced } \\
\text { diabetic rats }\end{array}$ & [120] \\
\hline & P. biglobosa & Fermented seeds & Methanol and aqueous & $\begin{array}{l}\text { Reduced fasting plasma glucose in alloxan-induced } \\
\text { diabetic rats }\end{array}$ & {$[160,161]$} \\
\hline & P. biglobosa & Seeds & Protein & $\begin{array}{l}\text { Significantly increased lipid peroxidation product levels } \\
\text { in brain and testes of diabetic rats }\end{array}$ & [226] \\
\hline & P. biglobosa & Seeds & $\begin{array}{l}\text { Methanol and fractions (chloroform and } \\
\text { n-hexane) }\end{array}$ & $\begin{array}{l}\text { Showed glucose-lowering effect } \\
\text { Activity: chloroform }>\text { methanol }>\text { n-hexane }\end{array}$ & [40] \\
\hline & P. javanica & Fruits & Ethyl acetate fraction & $\begin{array}{l}\text { Reduced blood glucose inhibited } \alpha \text {-glucosidase and } \\
\alpha \text {-amylase in streptozotocin-induced diabetic rats }\end{array}$ & [18] \\
\hline \multirow{6}{*}{$\begin{array}{l}\text { Antitumor/ } \\
\text { Anticancer }\end{array}$} & P javanica & Fruits & Aqueous methanol & Increased apoptosis in sarcoma- 180 cancer cell lines & [227] \\
\hline & P javanica & Seeds & Methanol & $\begin{array}{l}\text { Caused 50\% death in HepG2 (liver cancer cell) but not } \\
\text { cytotoxic to normal cells }\end{array}$ & {$[44]$} \\
\hline & P javanica & Seeds & Lectin & $\begin{array}{l}\text { Inhibited proliferation in cancerous cell lines; P388DI and } \\
\text { J774, B-cell hybridoma and HB98 cell line }\end{array}$ & [173] \\
\hline & P. speciosa & Pods & Methanolic ethyl acetate fraction & $\begin{array}{l}\text { Showed selective cytotoxicity on breast cancer cells } \\
\text { MCF-7 }\end{array}$ & {$[170]$} \\
\hline & P. biglobosa & Leaves and stem & Methanol & $\begin{array}{l}\text { Antiproliferative effect in human cancer cells T-549, } \\
\text { BT-20, and PC-3 }\end{array}$ & [174] \\
\hline & P. filicoidea & Leaves & Methanol & $\begin{array}{l}\text { Antiproliferative effect in in human cancer cells T-549, } \\
\text { BT-20, and PC-3 }\end{array}$ & [174] \\
\hline $\begin{array}{l}\text { Antiproliferative and } \\
\text { anti-mutagenic }\end{array}$ & P. biglandulosa & Seeds & Lectin & $\begin{array}{l}\text { T cell mitogen and antiproliferative against P388DI and } \\
\text { J774 cancer cell lines }\end{array}$ & [173] \\
\hline
\end{tabular}


Table 3. Cont.

\begin{tabular}{|c|c|c|c|c|c|}
\hline Activity & Species & Part & Type of Extract/Compound & Key Findings & References \\
\hline \multirow{6}{*}{ Antihypertensive } & P. speciosa & Seeds & Aqueous & $\begin{array}{l}\text { Showed moderate ACE-inhibitory activity in } \\
\text { in vitro }\end{array}$ & [191] \\
\hline & P. speciosa & Seeds & Peptide & $\begin{array}{c}\text { Inhibited angiotensin-converting enzyme (ACE) } \\
\text { in rats. No effect observed in non-hydrolyzed } \\
\text { samples }\end{array}$ & {$[189,190]$} \\
\hline & P. speciosa & Pods & Methanol & $\begin{array}{l}\text { Prevented the increases in blood pressure and } \\
\text { angiotensin-converting enzyme (ACE) and } \\
\text { restored nitric oxide in hypertensive rat model }\end{array}$ & [112] \\
\hline & P. biglobosa & Stem bark & Aqueous & $\begin{array}{l}\text { Induced hypotension in adrenaline-induced } \\
\text { hypertensive rabbits }\end{array}$ & [181] \\
\hline & P. biglobosa & Roasted and fermented seeds & Aqueous & $\begin{array}{l}\text { Induced relaxation in rat aorta precontracted with } \\
\text { phenylephrine in the presence or absence of } \\
\text { endothelium. }\end{array}$ & [180] \\
\hline & P. biglobosa & fermented seeds & Aqueous & $\begin{array}{l}\text { Lower blood pressure, blood glucose, and heart } \\
\text { rate, high level of magnesium as well as improved } \\
\text { lipid profile in patients with hypertension }\end{array}$ & [178] \\
\hline \multirow[t]{3}{*}{ Antidiarrheal } & P. biglobosa & Leaves and stem bark & Aqueous and ethanol & $\begin{array}{l}\text { Reduced frequency of stooling in castor-oil } \\
\text { induced diarrhea in rats }\end{array}$ & [193] \\
\hline & P. biglobosa & Stem-bark & $70 \%$ Methanol & $\begin{array}{l}\text { The extract exhibited } 100 \% \text { protections at } 100 \text { and } \\
200 \mathrm{mg} / \mathrm{kg} \text { bw in the diarrheal rats }\end{array}$ & [59] \\
\hline & P. filicoidea & Stem bark & Aqueous & $\begin{array}{l}\text { Reduced frequency of stooling and improved } \\
\text { transit time at } 100 \text { and } 200 \mathrm{mg} / \mathrm{kg} \mathrm{bw}\end{array}$ & [192] \\
\hline \multirow{3}{*}{ Antiulcer } & P. speciosa & Leaves & Ethanol & $\begin{array}{l}\text { Reduced mucosal injury and increased in periodic } \\
\text { acid-Schiff (PAS) staining induced by ethanol }\end{array}$ & [198] \\
\hline & P. speciosa & Seed & Ethanol & $\begin{array}{l}\text { Decreased gastric juice acidity, lesion length, } \\
\text { collagen content and fibrosis in } \\
\text { indomethacin-induced peptic ulcer in rats }\end{array}$ & [197] \\
\hline & P. platycephala & Leaves & Ethanol & $\begin{array}{l}\text { Reduced gastric mucosal lesion induced by } \\
\text { ethanol, ischemia-reperfusion and ethanol- } \mathrm{HCl}\end{array}$ & [199] \\
\hline
\end{tabular}


Table 3. Cont.

\begin{tabular}{|c|c|c|c|c|c|}
\hline Activity & Species & Part & Type of Extract/Compound & Key Findings & References \\
\hline \multirow{3}{*}{ Antianemic } & P. biglobosa & $\begin{array}{c}\text { Combination of } \\
\text { fermented seed with } \\
\text { other fermented products }\end{array}$ & Aqueous & $\begin{array}{l}\text { Increased hemoglobin, red blood cell, white blood } \\
\text { cell levels and packed cell volume in albino rats }\end{array}$ & [204] \\
\hline & P. biglobosa & Seeds & Ethanol & $\begin{array}{l}\text { Increased hemoglobin levels in } \mathrm{NaNO}_{2} \text {-induced } \\
\text { anemic mice }\end{array}$ & [205] \\
\hline & P. speciosa & Seeds & Ethanol & $\begin{array}{l}\text { Increased hemoglobin levels in } \mathrm{NaNO}_{2} \text {-induced } \\
\text { anemic mice }\end{array}$ & [205] \\
\hline \multirow[t]{2}{*}{ Antiangiogenic } & P.biglandulosa & Fruit and $\beta$-sitosterol & Ethanol & $\begin{array}{c}\text { The extract and the isolated compound showed } \\
\text { antiangiogenic activity on the caudal fin of adult } \\
\text { zebrafish }\end{array}$ & [175] \\
\hline & P. speciosa & Pods & Methanol and water sub-extract & $\begin{array}{l}\text { Inhibited more than } 50 \% \text { micro vessel outgrowth } \\
\text { in rat aortae and HUVECs }\end{array}$ & [170] \\
\hline Antimalarial & P. biglobosa & Stem bark & Methanol and fractions & $\begin{array}{l}\text { Showed antiplasmodial activity caused by } \\
\text { P. berghei and P. falciparum }\end{array}$ & [11] \\
\hline Nephroprotective & P. clappertoniana & Seed & Aqueous & $\begin{array}{l}\text { Reduced serum creatinine, } \mathrm{Na} \text {, urine proteins and } \\
\text { leukocytes and kidney weight in } \\
\text { gentamicin-induced renal damage in rats }\end{array}$ & [75] \\
\hline Hepatoprotective & P. biglobosa & Stem barks & Methanol & $\begin{array}{c}\text { Reduced serum alanine and aspartate } \\
\text { transaminases, and alkaline phosphatase in } \\
\text { paracetamol-induced hepatotoxicity rat model }\end{array}$ & [216] \\
\hline Wound healing & P. pendula & Seeds & Lectin & $\begin{array}{l}\text { Increased skin wound repair in } \\
\text { immunosuppressed mice }\end{array}$ & [217] \\
\hline \multirow{2}{*}{ Anti-inflammatory } & P. speciosa & Pods & Ethyl acetate fraction & $\begin{array}{c}\text { Reduced iNOS activity, COX-2, VCAM-1 and } \\
\text { NF- } k \text { B expressions in cardiomyocytes exposed to } \\
\text { tumor necrosis factor- } \alpha\end{array}$ & [229] \\
\hline & P. speciosa & Pods & Ethyl acetate fraction & $\begin{array}{c}\text { Reduced iNOS activity, COX-2, VCAM-1 and } \\
\text { NF- } \mathrm{kB} \text { expressions in HUVECs exposed to tumor } \\
\text { necrosis factor- } \alpha\end{array}$ & [230] \\
\hline
\end{tabular}


Table 3. Cont

\begin{tabular}{|c|c|c|c|c|c|}
\hline Activity & Species & Part & Type of Extract/Compound & Key Findings & References \\
\hline & P. biglobosa & Stalk & Methanol & $\begin{array}{l}\text { Inhibited croton pellet granuloma formation and } \\
\text { carrageenin-induced rat paw edema }\end{array}$ & [206] \\
\hline & P. biglobosa & Seeds & Lectin & $\begin{array}{l}\text { Lectin showed anti-inflammatory effect by } \\
\text { inhibition of pro-inflammatory cytokine release } \\
\text { and stimulation of anti-inflammatory cytokine } \\
\text { release on peritonitis induced model mice }\end{array}$ & [208] \\
\hline & P. biglobosa & Stem bark & Hexane & $\begin{array}{l}\text { Reduced carrageenan- and PMA-induced edema } \\
\text { in mice }\end{array}$ & [29] \\
\hline & P. biglobosa & Fruit & $70 \%$ Methanol & $\begin{array}{l}\text { Increased percentage protection of the human red } \\
\text { blood cell membrane }\end{array}$ & [209] \\
\hline & P. platycephala & Seeds & Lectin & $\begin{array}{l}\text { Lectin showed antinociceptive effect in the mouse } \\
\text { model of acetic acid-induced }\end{array}$ & [207] \\
\hline \multirow{6}{*}{ Antioxidant } & P. javanica & Leaves & Hexane, ethyl acetate, and methanol & $\begin{array}{l}\text { Methanol extract showed the highest antioxidant } \\
\text { potential activities (DPPH test) of about } 85 \% \text { and } \\
\text { (FRAP test) of about } 0.9 \mathrm{mM} \mathrm{Fe} \text { (II) } / \mathrm{g} \text { dry }\end{array}$ & [231] \\
\hline & P. javanica & Leaves & Aqueous, ethanol and methanol & $\begin{array}{c}\text { All the extracts exhibited good antioxidant } \\
\text { activity. The aqueous extract showed the highest } \\
\text { values of } 47.42 \text { and } 26.6 \mathrm{mg} \text { of ascorbic acid } \\
\text { equivalent/g in DPPH and FRAP tests, } \\
\text { respectively }\end{array}$ & [232] \\
\hline & P. javanica & Pods & Methanol and acetone & $\begin{array}{l}\text { High content of total phenolic and flavonoid. } \\
\text { Showed high reducing power and strong radical } \\
\text { scavenging activity. }\end{array}$ & [212] \\
\hline & P. javanica & Fruit & Methanol & $\begin{array}{l}\text { Showed increased DPPH and ferric-reducing } \\
\text { power activities concentration-dependently }\end{array}$ & [210] \\
\hline & P. speciosa & Pod & Methanol & Increased DPPH scavenging activity & [233] \\
\hline & P. speciosa & Pod & Ethyl acetate fraction & $\begin{array}{l}\text { Reduced NOX4, SOD1, p38 MAPK protein } \\
\text { expressions and ROS level }\end{array}$ & [230] \\
\hline
\end{tabular}


Table 3. Cont

\begin{tabular}{|c|c|c|c|c|c|}
\hline Activity & Species & Part & Type of Extract/Compound & Key Findings & References \\
\hline & P. speciosa & Pod & Aqueous and ethanolic & $\begin{array}{c}\text { Increased DPPH and ABTS scavenging activities, } \\
\text { reduced lipid peroxidation Activity: ethanol > } \\
\text { aqueous }\end{array}$ & [107] \\
\hline & P. speciosa & Seeds & Ethanol & $\begin{array}{c}\text { Extract exhibited significant activity (DPPH and } \\
\text { FRAP tests) }\end{array}$ & [213] \\
\hline & P. speciosa & Seed coats and pods & Ethanol & $\begin{array}{c}\text { Reduced Heinz body formation in erythrocytes } \\
\text { incubated with acetyl phenylhydrazine. } \\
\text { Activity: seed coat }>\text { pods }>\end{array}$ & [215] \\
\hline & P. speciosa & Pods & Ethanol & Increased DPPH scavenging activity & [234] \\
\hline & P. biglobosa & Fermented and unfermented seed & Aqueous & $\begin{array}{l}\text { Fermented seed increased reduction of } \mathrm{Fe}^{3+} \text { to } \\
\qquad \mathrm{Fe}^{2+}\end{array}$ & [211] \\
\hline & P. biglobosa & Stem bark & Aqueous-methanolic & $\begin{array}{l}\text { Mitigated ferric-induced lipid peroxidation in rat } \\
\text { tissues and increased scavenging activities against } \\
\text { DPPH and ABTS, ferric-reducing ability }\end{array}$ & [235] \\
\hline & P. biglobosa & Fruit & Methanol and hydro-ethanol & $\begin{array}{c}\text { Increased DPPH scavenging activity and reducing } \\
\text { power. }\end{array}$ & [210] \\
\hline & P. biglobosa & Fruit & Hydroethanolic and methanol & $\begin{array}{l}\text { Increased scavenging activity against DPPH free } \\
\text { radical } \\
\text { Activity: methanol }>\text { hydroethanolic }\end{array}$ & [210] \\
\hline
\end{tabular}

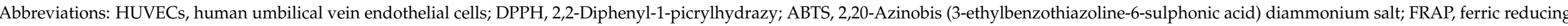

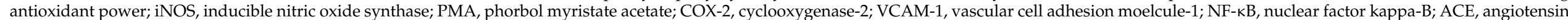
converting enzyme; HEL, human embryo lung; PAS, periodic acid-Schiff; bw, body weight. 


\section{Conclusions}

Enormous reports demonstrate that plants from genus Parkia possess medicinal values, attributable to the presence of pharmacological active compounds. Taken together, two most studied species, P. biglobosa and P. speciosa, show potential as antidiabetic, antihypertensive, and antimicrobial, to name a few. Phytochemical investigations indicated terpenoids (monoterpenoids, diterpenoids, and triterpenoids), phenolics acids and flavonoids (flavonols, isoflavone, flavanone, and flavan-3-ols) are the major chemical constituents present in the species of this genus, which are responsible for their diverse pharmacological activities. It seems that certain phytoconstituents in Parkia have their unique pharmacological effects. $\beta$-Sitosterol and stigmasterol, for instance, could be investigated further and be developed as hypoglycemic agents; cyclic polysulfides, such as antimicrobials; lectins and monosaccharide saponins for anticancer treatment; and polyphenols, most possibly catechin and its derivatives, and active peptides for blood pressure-lowering effect. The pharmacological properties studied in vitro and in vivo of these compounds should be confirmed in clinical studies. In order to carry out this, there is a need to develop a method, which is effective and cheap to isolate the bioactive constituents in bulks. The potential toxicity and safety of the compounds, as well as their possible protective mechanisms, should also be determined before administration into humans. However, research on other bioactive compounds should continue. It is hoped that discoveries of novel agents from these plants could provide an alternative to the current modern medicine.

Author Contributions: M.S.M.S. drafted and edited the manuscript. J.J., S.Z., A.Y.A., N.H.M. and Y.K. revised the manuscript. All authors have read and agreed to the published version of the manuscript.

Funding: The work was supported by the Ministry of Education Malaysia grant (FRGS/1/2019/ SKK10/UKM/02/1).

Data Availability Statement: Data is contained within the article.

Conflicts of Interest: All authors declare no conflict of interest.

\section{References}

1. Heymann, E.W.; Lüttmann, K.; Michalczyk, I.M.; Saboya, P.P.P.; Ziegenhagen, B.; Bialozyt, R. DNA fingerprinting validates seed dispersal curves from observational studies in the neotropical legume Parkia. PLoS ONE 2012, 7, e35480. [CrossRef] [PubMed]

2. Orwa, C.; Mutua, A.; Kindt, R.; Jamnadass, R.; Simons, A. Agroforestree Database: A Tree Reference and Selection Guide, version 4; World Agroforestry Centre: Nairobi, Kenya, 2009.

3. Luckow, M.; Hopkins, H.C.F. A cladistic analysis of Parkia (Leguminosae: Mimosoideae). Am. J. Bot. 1995, 82, 1300-1320. [CrossRef]

4. Neill, D.A. Parkia nana (Leguminosae, Mimosoideae), a new species from the sub-Andean sandstone cordilleras of Peru. Novon A J. Bot. Nomencl. 2009, 19, 204-208. [CrossRef]

5. Ching, L.S.; Mohamed, S. Alpha-tocopherol content in 62 edible tropical plants. J. Agric. Food Chem. 2001, 49, 3101-3105. [CrossRef] [PubMed]

6. Suvachittanont, W.; Peutpaiboon, A. Lectin from Parkia speciosa seeds. Phytochemistry 1992, 31, 4065-4070. [CrossRef]

7. Ogunyinka, B.I.; Oyinloye, B.E.; Osunsanmi, F.O.; Kappo, A.P.; Opoku, A.R. Comparative study on proximate, functional, mineral, and antinutrient composition of fermented, defatted, and protein isolate of Parkia biglobosa seed. Food Sci. Nutr. 2017, 5, 139-147. [CrossRef] [PubMed]

8. Alabi, D.A.; Akinsulire, O.R.; Sanyaolu, M.A. Qualitative determination of chemical and nutritional composition of Parkia biglobosa (Jacq.) Benth. Afr. J. Biotechnol. 2005, 4, 812-815. [CrossRef]

9. Fetuga, B.L.; Babatunde, G.M.; Oyenuga, V.A. Protein quality of some unusual protein foodstuffs. Studies on the African locust-bean seed (Parkia filicoidea Welw.). Br. J. Nutr. 1974, 32, 27-36. [CrossRef]

10. Hassan, L.G.; Umar, K.J. Protein and amino acids composition of African locust bean (Parkia biglobosa). Trop. Subtrop. Agroecosyst. 2005, 5, 45-50.

11. Builders, M.; Alemika, T.; Aguiyi, J. Antimalarial Activity and isolation of phenolic compound from Parkia biglobosa. IOSR J. Pharm. Biol. Sci. 2014, 9, 78-85. [CrossRef]

12. Ifesan, B.O.T.; Akintade, A.O.; Gabriel-Ajobiew, R.A.O. Physicochemical and nutritional properties of Mucuna pruriens and Parkia biglobosa subjected to controlled fermentation. Int. Food Res. J. 2017, 24, 2177-2184.

13. Iheke, E.; Oshodi, A.; Omoboye, A.; Ogunlalu, O. Effect of fermentation on the physicochemical properties and nutritionally valuable minerals of locust bean (Parkia biglobosa). Am. J. Food Technol. 2017, 6, 379-384. [CrossRef] 
14. Abdullahi, I.N.; Chuwang, P.Z.; Anjorin, T.S.; Ikemefuna, H. Determination of Mineral Accumulation through Litter Fall of Parkia Biglobosa Jacq Benth and Vitellaria Paradoxa Lahm Trees in Abuja, Nigeria. Int. J. Sci. Res. Agric. Sci. 2015, 2, $0016-0021$.

15. Singh, N.P.; Gajurel, P.R.; Rethy, P. Ethnomedicinal value of traditional food plants used by the Zeliang tribe of Nagaland. Indian J. Tradit. Knowl. 2015, 14, 298-305.

16. Mondal, P.; Bhuyan, N.; Das, S.; Kumar, M.; Borah, S.; Mahato, K. Herbal medicines useful for the treatment of diabetes in north-east India: A review. Int. J. Pharm. Biol. Sci. 2013, 3, 575-589.

17. Boye, A.; Boampong, V.A.; Takyi, N.; Martey, O. Assessment of an aqueous seed extract of Parkia clappertoniana on reproductive performance and toxicity in rodents. J. Ethnopharmacol. 2016, 185, 155-161. [CrossRef]

18. Sheikh, Y.; Maibam, B.C.; Talukdar, N.C.; Deka, D.C.; Borah, J.C. In vitro and in vivo anti-diabetic and hepatoprotective effects of edible pods of Parkia roxburghii and quantification of the active constituent by HPLC-PDA. J. Ethnopharmacol. 2016, 191, 21-28. [CrossRef]

19. Singh, M.K. Potential of underutilized legume tree Parkia timoriana (DC.) Merr. In Eco-restoration of Jhum fallows of Manipur. J. Pharmacogn. Phytochem. 2019, 8, 1685-1687.

20. Roosita, K.; Kusharto, C.M.; Sekiyama, M.; Fachrurozi, Y.; Ohtsuka, R. Medicinal plants used by the villagers of a Sundanese community in West Java, Indonesia. J. Ethnopharmacol. 2008, 115, 72-81. [CrossRef]

21. Srisawat, T.; Suvarnasingh, A.; Maneenoon, K. Traditional medicinal plants notably used to treat skin disorders nearby Khao Luang mountain hills region, Nakhon si Thammarat, Southern Thailand. J. HerbsSpices Med. Plants 2016, 22, 35-56. [CrossRef]

22. Aiyelaagbe, O.O.; Ajaiyeoba, E.O.; Ekundayo, O. Studies on the seed oils of Parkia biglobosa and Parkia bicolor. Plant Foods Hum. Nutr. 1996, 49, 229-233. [CrossRef] [PubMed]

23. Ajaiyeoba, E. 0 Phytochemical and antibacterial properties of Parkia biglobosa and Parkia bicolor leaf extracts. Afr. J. Biomed. Res. 2002, 5, 125-129. [CrossRef]

24. Oladunmoye, M.K.; Kehinde, F.Y. Ethnobotanical survey of medicinal plants used in treating viral infections among Yoruba tribe of South Western Nigeria. Afr. J. Microbiol. Res. 2011, 5, 2991-3004. [CrossRef]

25. Rathi, R.S.; Misra, A.K.; Somnath, R.; Verma, S.K.; Singh, S.K. Potential of a lesser known tree species Parkia roxburghii G. Don of North East India. Indian For. 2012, 138, 476-479.

26. Ong, H.C.; Ahmad, N.; Milow, P. Traditional Medicinal Plants Used by the Temuan Villagers in Kampung Tering, Negeri Sembilan, Malaysia. Stud. Ethno-Med. 2011, 5, 169-173. [CrossRef]

27. Ong, H.C.; Chua, S.; Milow, P. Ethno-medicinal plants used by the Temuan villagers in Kampung Jeram Kedah, Negeri Sembilan, Malaysia. Stud. Ethno-Med. 2011, 5, 95-100. [CrossRef]

28. Fotie, J.; Nkengfack, A.E.; Peter, M.G.; Heydenreich, M.; Fomum, Z.T. Chemical constituents of the ethyl acetate extracts of the stem bark and fruits of Dichrostachys cinerea and the roots of Parkia bicolor. Bull. Chem. Soc. Ethiop. 2004, 18, 111-115. [CrossRef]

29. Kouadio, F.; Kanko, C.; Juge, M.; Grimaud, N.; Jean, A.; N'Guessan, Y.T.; Petit, J.Y. Analgesic and antiinflammatory activities of an extract from Parkia biglobosa used in traditional medicine in the ivory coast. Phytother. Res. 2000, 14, 635-637. [CrossRef]

30. Ong, H.C.; Zuki, R.M.; Milow, P. Traditional Knowledge of Medicinal Plants among the Malay Villagers in Kampung Mak Kemas, Terengganu, Malaysia. Stud. Ethno-Med. 2011, 2011, 175-185. [CrossRef]

31. Millogo-Kone, H.; Guissou, I.P.; Nacoulma, O.; Traore, A.S. Antimicrobial effects of the stem bark extracts of Parika biglobosa (Jacq.)Benth. on Shigellae. Afr. J. Tradit. Complementary Altern. Med. 2007, 4, 392-396. [CrossRef]

32. Enujiugha, V.N. The antioxidant and free radical-scavenging capacity of phenolics from African locust bean seeds (Parkia biglobosa). Adv. Food Sci. 2010, 32, 88-93.

33. Gernah, D.I.; Inyang, C.U.; Ezeora, N.L. Incubation and fermentation of African locust beans (Parkia biglobosa) in production of 'dawadawa'. J. Food Process. Preserv. 2007, 31, 227-239. [CrossRef]

34. El-Mahmood, A.M.; Ameh, J.M. In vitro antibacterial activity of Parkia biglobosa (Jacq.) root bark extract against some microorganisms associated with urinary tract infections. Afr. J. Biotechnol. 2007, 6, 1272-1275. [CrossRef]

35. Adaramola, T.F.; Ariwaodo, J.O.; Adeniji, K.A. Distribution, phytochemistry and antioxidant properties of the genus Parkia R.br. (mimosaceae) in Nigeria. Int. J. Pharmacogn. Phytochem. Res. 2012, 4, 172-178.

36. Builders, M. Toxicity studies of the extracts of Parkia biglobosa Stem Bark in Rats. Br. J. Pharm. Res. 2012, 2, 1-16. [CrossRef]

37. Chhikara, N.; Devi, H.R.; Jaglan, S.; Sharma, P.; Gupta, P.; Panghal, A. Bioactive compounds, food applications and health benefits of Parkia speciosa (stinky beans): A review. Agric. Food Secur. 2018, 7, 1-9. [CrossRef]

38. Udobi, C.E.; Onaolapo, J.A. Phytochemical analysis and antibacterial evaluation of the leaf stem bark and root of the African locust bean (Parkia biglobosa). J. Med. Plants Res. 2009, 3, 338-344.

39. Ezema, B.E.; Eze, F.U.; Ezeofor, C.C. Phytochemical and antibacterial studies of eastern nigerian mistletoe (Loranthus micranthus) parasitic on Pentacletra macrophylla and Parkia biglobosa. Int. J. Pharm. Technol. Res. 2016, 9, 360-365.

40. Fred-Jaiyesimi, A.A.; Abo, K.A. Hypoglycaemic effects of Parkia biglobosa (Jacq) Benth seed extract in glucose-loaded and NIDDM rats. Int. J. Biol. Chem. Sci. 2009, 3, 545-550. [CrossRef]

41. Mohan, V.R.; Janardhanan, K. Chemical and nutritional evaluation of raw seeds of the tribal pulses Parkia roxburghii G. Don. and Entada phaseoloides (L.) Merr. Int. J. Food Sci. Nutr. 1993, 44, 47-53. [CrossRef]

42. Dinda, B.; Chandra Mohanta, B.; Debnath, S.; Ghosh, B.; Arima, S.; Sato, N.; Harigaya, Y. Iridoid glucosides from leaves and stem barks of Parkia javanica. J. Asian Nat. Prod. Res. 2009, 11, 229-235. [CrossRef] [PubMed] 
43. Abioye, E.O.; Akinpelu, D.A.; Aiyegoro, O.A.; Adegboye, M.F.; Oni, M.O.; Okoh, A.I. Preliminary phytochemical screening and antibacterial properties of crude stem bark extracts and fractions of Parkia biglobosa (Jacq.). Molecules 2013, 18, 8485-8499. [CrossRef] [PubMed]

44. Chanu, K.V.; Geeta Devi, L.; Kumar Srivastava, S.; Telang, A.; Khangembam Victoria Chanu, C.; Thakuria, D.; Kataria, M. Phytochemical analysis and evaluation of anticancer activity of Parkia javanica seeds. Pharma Innov. J. 2018, 7, 305-311.

45. Tijani, A.Y.; Okhale, S.E.; Salawu, T.A.; Onigbanjo, H.O.; Obianodo, L.A.; Akingbasote, J.A.; Salawu, O.A.; Okogun, J.I.; Kunle, F.O.; Emeje, M. Antidiarrhoeal and antibacterial properties of crude aqueous stem bark extract and fractions of Parkia biglobosa (Jacq) R. Br. Ex G. Don. Afr. J. Pharm. Pharmacol. 2009, 3, 347-353.

46. Awotedu, O.L.; Ogunbamowo, P.O.; Emmanuel, I.B.; Lawal, I.O. Phytominerals and Phytochemical Studies of Azadiracthta indica, Leea guineensis and Parkia biglobosa Leaves. Int. Ann. Sci. 2018, 6, 28-34. [CrossRef]

47. Fayinminnu, O.O.; Adeniyi, O.O.; Alabi, O.Y.; Omobusuyi, D.O. Potentials of Aqueous Extract of Pod Husk Parkia biglobosa (Jacq.) Benth as a Biopesticide in Okra (Abelmoschus esculentus (L.) Moench) Production. J. Agric. Ecol. Res. Int. 2017, 1-12. [CrossRef]

48. Sani, U.M. Phytochemical screening and antifeedant activity of the seed extracts of Parkia biglobosa against cowpea vean (Vigna unguiculata) storage pest (Callosobruchus maculatus). Int. J. Innov. Sci. Eng. Technol. 2014, 3, 15991-15995. [CrossRef]

49. Soetan, K.O.; Lasisi, O.T.; Agboluaje, A.K. Comparative assessment of in-vitro anthelmintic effects of the aqueous extracts of the seeds and leaves of the African locust bean (Parkia biglobosa) on bovine nematode eggs. J. Cell Anim. Biol. $2011,5,109-112$.

50. Iyamu, M.I.; Ekozien, M.I.; Omoigberale, M.N.O. Phytochemical screening and antibacterial activity of the stem back of African Locust bean plant (Parkia Filicoidea Welw.). Glob. J. Biol. Agric. Health Sci. 2014, 3, 36-43.

51. Salam, S.; Jamir, N.S.; Singh, P.K. Traditional uses of medicinal plants by the Tangkhul-Naga tribe in Manipur, India. Pleione 2009, 3, 157-162.

52. Salam, J.S.; Salam, P.; Potshangbam, K.S.; Kumar, D.B. Effect of processing methods on secondary metabolites and enzyme inhibitors in different developmental stages of Parkia roxburghii G. Don pods. Am. J. Food Technol. 2014, 9, 89-96.

53. Costa, B.A.; de Oliveira, J.M.; Sales, P.A.; Lira, S.R.D.S.; Silva, S.M.D.S.; Costa, L.M.; Muratori, M.; Costa, A.P. Systemic and reproductive toxicity induced by Parkia platycephala ethanolic extract in female Wistar rats. Braz. J. Pharmacogn. 2013, 23, 920-926. [CrossRef]

54. SáSantos, M.M.; da Silva, F.M.P.; da Silva, J.F.M.; Pimenta, R.S. Phytochemistry and antibacterial activity of aqueous and hydroalcoholic extracts of three medicinal plants against food pathogens. Acta Sci. Biol. Sci. 2018, 40, 1-6. [CrossRef]

55. Lawal, I.O.; Uzokwe, N.E.; Igboanugo, A.B.I.; Adio, A.F.; Awosan, E.A.; Nwogwugwu, J.O.; Faloye, B.; Olatunji, B.P.; Adesoga, A.A. Ethno medicinal information on collation and identification of some medicinal plants in Research Institutes of South-west Nigeria. Afr. J. Pharm. Pharmacol. 2010, 4, 1-7.

56. Henry, S.G.; Francis, A.; Kofi, A. Ethnobotanical survey of medicinal plants used for the treatment of diarrhoea and skin ulcer in the Brong Ahafo region of Ghana. J. Med. Plants Res. 2013, 7, 3280-3285. [CrossRef]

57. Campbell-Platt, G. African locust bean (Parkia species) and its west african fermented food product, dawadawa. Ecol. Food Nutr. 1980, 9, 123-132. [CrossRef]

58. Igoli, J.O.; Ogaji, O.G.; Tor-Anyiin, T.A.; Igoli, N.P. Traditional medicine practice amongst the Igede people of Nigeria. Part II. Afr. J. Tradit. Complementary Altern. Med. 2005, 2, 134-152. [CrossRef]

59. Agunu, A.; Yusuf, S.; Andrew, G.O.; Zezi, A.U.; Abdurahman, E.M. Evaluation of five medicinal plants used in diarrhoea treatment in Nigeria. J. Ethnopharmacol. 2005, 101, 27-30. [CrossRef]

60. Asuzu, I.U.; Harvey, A.L. The antisnake venom activities of Parkia biglobosa (Mimosaceae) stem bark extract. Toxicon 2003, 42, 763-768. [CrossRef]

61. Karou, S.D.; Tchacondo, T.; Djikpo Tchibozo, M.A.; Abdoul-Rahaman, S.; Anani, K.; Koudouvo, K.; Batawila, K.; Agbonon, A.; Simpore, J.; de Souza, C. Ethnobotanical study of medicinal plants used in the management of diabetes mellitus and hypertension in the Central Region of Togo. Pharm. Biol. 2011, 49, 1286-1297. [CrossRef]

62. Grønhaug, T.E.; Glæserud, S.; Skogsrud, M.; Ballo, N.; Bah, S.; Diallo, D.; Paulsen, B.S. Ethnopharmacological survey of six medicinal plants from Mali, West-Africa. J. Ethnobiol. Ethnomed. 2008, 4, 26. [CrossRef] [PubMed]

63. Abo, K.A.; Fred-Jaiyesimi, A.A.; Jaiyesimi, A.E.A. Ethnobotanical studies of medicinal plants used in the management of diabetes mellitus in South Western Nigeria. J. Ethnopharmacol. 2008, 115, 67-71. [CrossRef] [PubMed]

64. Pare, D.; Hilou, A.; Ouedraogo, N.; Guenne, S. Ethnobotanical study of medicinal plants used as anti-obesity remedies in the nomad and hunter communities of Burkina Faso. Medicines 2016, 3, 9. [CrossRef] [PubMed]

65. Millogo-Kone, H.; Guissoe, P.I.; Nacoulma, O.; Traore, A.S. Study of the antibacterial activity of the stem bark and leaf extracts of Parkia biglobosa (Jacq.) Benth. on Satphylococcus aureus. Afr. J. Tradit. Complementary Altern. Med. 2006, 3, 74-78. [CrossRef]

66. Quansah, L.; Mahunu, G.K.; Tahir, H.E.; Mariod, A.A. Parkia biglobosa: Phytochemical Constituents, Bioactive Compounds, Traditional and Medicinal Uses. In Wild Fruits: Composition, Nutritional Value and Products; Springer: Berlin/Heidelberg, Germany, 2019; pp. 271-284.

67. Abreu, P.M.; Martins, E.S.; Kayser, O.; Bindseil, K.U.; Siems, K.; Seemann, A.; Frevert, J. Antimicrobial, antitumor and antileishmania screening of medicinal plants from Guinea-Bissau. Phytomedicine 1999, 6, 187-195. [CrossRef]

68. Rupesh, P.; Pal, S.C.; Pavani, A.; Gadge, M.S. Quantitave estimation of the active constituents of Parkia biglandulosa by using HPTLC and FTIR. Int. J. Pharma Bio Sci. 2010, 1, 315-332. 
69. Khond, M.; Bhosale, J.D.; Arif, T.; Mandal, T.K.; Padhi, M.M.; Dabur, R. Screening of some selected medicinal plants extracts for in-vitro antimicrobial activity. Middle-East J. Sci. Res. 2009, 4, 271-278.

70. Pingale, R.; Pokharkar, D.; Phadatare, S.P.; Gorle, A. Pharmacognostic Evaluation of Parkia biglandulosa bark. Int. J. Pharm. Phytochem. Res. 2016, 8, 1160-1163.

71. Banwo, G.O.; Abdullahi, I.; Duguryil, M. The antimicrobial activity of the stem-bark and leaf of Parkia clappertoniana Keay family Leguminosae against selected microorganisms. Niger. J. Pharm. Res. 2004, 3, 16-22. [CrossRef]

72. Nwodo, N.J.; Ibezim, A.; Ntie-Kang, F.; Adikwu, M.U.; Mbah, C.J. Anti-trypanosomal activity of Nigerian plants and their constituents. Molecules 2015, 20,7750-7771. [CrossRef]

73. Lawal, M.S.; Sani, A.M.; Dangmwan, D.S.; Yahaya, U. Antimicrobial potentials of Parkia clappertoniana Jacq, Boswellia dalzielli hutch and Carica papaya L. ethanolic extract on multi-drug resistant Diarrheal salmonallae and Shigellae Bacteria. Biochem. Mol. Biol. 2016, 1, 27.

74. Muazu, J.; Kaita, M.H. A review of traditional plants used in the treatment of epilepsy amongst the Hausa/Fulani tribes of northern Nigeria. Afr. J. Tradit. Complementary Altern. Med. 2008, 5, 387-390. [CrossRef] [PubMed]

75. Boye, A. Nephroprotective and curative assessment of an aqueous seed extract of Parkia clappertoniana keay in gentamicin-induced renal damage in Sprague-dawley rats. Eur. J. Med. Plants 2014, 4, 234-248. [CrossRef]

76. Patrick-Iwuanyanwu, K.C.; Wegwu, M.O.; Okiyi, J.K. Hepatoprotective effects of African locust bean (Parkia clappertoniana) and negro pepper (Xylopia aethiopica) in CCl4-induced liver damage in wistar albino rats. Int. J. Pharmacol. 2010, 6, 744-749. [CrossRef]

77. Obata, O.O.; Aigbokhan, E.I. Ethnobotanical practices among the people of Okaakoko, Nigeria. Plant Arch. 2012, 12, 627-638.

78. Van Andel, T.; Behari-Ramdas, J.; Havinga, R.; Groenendijk, S. The medicinal plant trade in Suriname. Ethnobot. Res. Appl. 2007, 5, 351-372. [CrossRef]

79. Ferreira, A.B.; Ming, L.C.; Haverroth, M.; Daly, D.C.; Caballero, J.; Ballesté, A.M. Plants used to treat malaria in the regions of Rio Branco-Acre state and southern Amazonas state-Brazil. Int. J. Phytocosmetics Nat. Ingred. 2015, 2, 9. [CrossRef]

80. Mitra, R.; Orbell, J.; Muralitharan, M. Medicinal plants of Malaysia. Asia Pac. Biotech News 2007, 11, 105-110. [CrossRef]

81. Siew, Y.Y.; Zareisedehizadeh, S.; Seetoh, W.G.; Neo, S.Y.; Tan, C.H.; Koh, H.L. Ethnobotanical survey of usage of fresh medicinal plants in Singapore. J. Ethnopharmacol. 2014, 155, 1450-1466. [CrossRef]

82. Ripen, J.E.; Noweg, G.T. Economic valuation of medicinal plants in Jagoi Area, Bau, Malaysia. Procedia Soc. Behav. Sci. 2016, 224, 124-131. [CrossRef]

83. Eswani, N.; Kudus, K.A.; Nazre, M.; Noor, A.G.A.; Ali, M. Medicinal plant diversity and vegetation analysis of logged over hill forest of Tekai Tembeling Forest Reserve, Jerantut, Pahang. J. Agric. Sci. 2010, 2, 189. [CrossRef]

84. Sonia, N.; Dsouza, M.R. Alisha Pharmacological evaluation of Parkia speciosa Hassk for antioxidant, anti-inflammatory, antidiabetic and anti-microbial activities in vitro. Int. J. Life Sci. Spec. Issue 2018, 11, 49-59.

85. Bahtiar, A.; Vichitphan, K.; Han, J. Leguminous plants in the Indonesian Archipelago: Traditional uses and secondary metabolites. Nat. Prod. Commun. 2017, 12, 461-472. [CrossRef]

86. Batoro, J.; Siswanto, D. Ethnomedicinal survey of plants used by local society in Poncokusumo district, Malang, East Java Province, Indonesia. Asian J. Med Biol. Res. 2017, 3, 158-167. [CrossRef]

87. Samuel, A.J.S.J.; Kalusalingam, A.; Chellappan, D.K.; Gopinath, R.; Radhamani, S.; Husain, H.A.; Muruganandham, V.; Promwichit, P. Ethnomedical survey of plants used by the Orang Asli in Kampung Bawong, Perak, West Malaysia. J. Ethnobiol. Ethnomed. 2010, 6, 5. [CrossRef]

88. Rai, P.K.; Lalramnghinglova, H. Ethnomedicinal plant resources of Mizoram, India: Implication of traditional knowledge in health care system. Ethnobot. Leafl. 2010, 2010, 6.

89. Irvine, F.R. Woody Plants of Ghana; Oxford University Press: England, UK, 1961.

90. Phumthum, M.; Balslev, H. Thai ethnomedicinal plants used for diabetes treatment. OBM ICM 2018, 3, 1-25. [CrossRef]

91. Khumbongmayum, A.; Khan, M.; Tripathi, R. Ethnomedicinal plants in the sacred groves of Manipur. Indian J. Tradit. Knowl. (IJTK) 2005, 4, 21-32.

92. Bhardwaj, S.; Gakhar, S.K. Ethnomedicinal plants used by the tribals of Mizoram to cure cuts \& wounds. Indian J. Tradit. Knowl. 2005, 4, 75-80.

93. Jamal, J.A.; Ghafar, Z.A.; Husain, K. Medicinal plants used for postnatal care in Malay traditional medicine in the Peninsular Malaysia. Pharmacogn. J. 2011, 3, 15-24. [CrossRef]

94. Nanda, Y.; Singson, N.; Rao, A.N. Ethnomedicinal plants of Thadou tribe of Manipur (India)-1. Pleione 2013, 7, $138-145$.

95. Lalmuanpuii, J.; Rosangkima, G.; Lamin, H. Ethno-medicinal practices among the Mizo ethnic group in Lunglei district, Ethno-medicinal practices among the Mizo ethnic group in Lunglei district, Mizoram. Sci. Vis. 2013, 12, $24-34$.

96. Khan, M.H.; Yadava, P.S. Antidiabetic plants used in Thoubal district of Manipur, Northeast India. Indian J. Tradit. Knowl. 2010, 9, 510-514.

97. Mullick, J.B.; Majumdar, T.; Reddy, K.V.R.; Mukherjee, S.; Sil, S.K. Activity of the medicinal plant Parkia Javanica against multidrug-resistant Neisseria gonorrhoeae and other clinical isolates. Asian J. Pharm. Clin. Res. 2019, 12, 83-86. [CrossRef]

98. Quattrocchi, U. CRC World Dictionary of Medicinal and Poisonous Plants: Common Names, Scientific Names, Eponyms, Synonyms, and Etymology (5 Volume Set); CRC Press: Boca Raton, FL, USA, 2012; ISBN 142008044X.

99. Das, A.; Das, M.C.; Sandhu, P.; Das, N.; Tribedi, P.; De, U.C.; Akhter, Y.; Bhattacharjee, S. Antibiofilm activity of Parkia javanica against Pseudomonas aeruginosa: A study with fruit extract. Rsc Adv. 2017, 7, 5497-5513. [CrossRef] 
100. Egamberdieva, D.; Ovidi, E.; Tiezzi, A.; Craker, L. Phytochemical and Pharmacological Properties of Medicinal Plants from Uzbekistan: A Review. J. Med. Act. Plants 2016, 5, 59-75. [CrossRef]

101. Saxena, M.; Saxena, J.; Nema, R.; Singh, D.; Gupta, A. Phytochemistry of medicinal plants. J. Pharmacogn. Phytochem. Phytochem. 2013, 1, 168-182. [CrossRef]

102. Tariq, A.L.; Reyaz, A.L. Significances and importance of phytochemical present in Terminalia chebula. Int. J. Drug Dev. Res. 2013, 5, 256-262.

103. Wadood, A.; Ghufran, M.; Jamal, S.B.; Naeem, M.; Khan, A.; Ghaffar, R. Phytochemical analysis of medicinal plants occurring in local area of Mardan. Biochem. Anal. Biochem. 2013, 2. [CrossRef]

104. Ahmad, N.I.; Rahman, S.A.; Leong, Y.H.; Azizul, N.H. A review on the phytochemicals of Parkia speciosa, stinky beans as potential phytomedicine. J. Food Sci. Nutr. Res. 2019, 2, 151-173. [CrossRef]

105. Sikolia, S.F.; Omondi, S. Phytochemical Analysis of Some Selected Plants and Families in the University Botanic Garden of Maseno, Kenya. IOSR J. Pharm. Biol. Sci. 2017, 12, 31-38. [CrossRef]

106. Tala, V.R.S.; Da Silva, V.C.; Rodrigues, C.M.; Nkengfack, A.E.; Dos Santos, L.C.; Vilegas, W. Characterization of proanthocyanidins from Parkia biglobosa (Jacq.) G. Don. (Fabaceae) by flow injection analysis-electrospray ionization ion trap tandem mass spectrometry and liquid chromatography/electrospray ionization mass spectrometry. Molecules 2013, 18, 2803-2820. [CrossRef] [PubMed]

107. Ko, H.J.; Ang, L.H.; Ng, L.T. Antioxidant activities and polyphenolic constituents of bitter bean Parkia speciosa. Int. J. Food Prop. 2014, 17, 1977-1986. [CrossRef]

108. Loukrakpam, B.; Rajendran, A.; Chyne, D.A.L.; Longvah, T. 12th IFDC 2017 Special Issue-Nutrient and phytonutrient profiles of some indigenous vegetables of Manipur, Northeast India. J. Food Compos. Anal. 2019, 79, 12-22. [CrossRef]

109. Mohammad, M.; Garba, M.A.; Haruna, A.; Jimoh, A.A. Characterization of naringenin from the fruit pulp extract of Parkia biglobosa (FABACEAE). Fuw Trends Sci. Technol. J. 2018, 4, 918-920.

110. Dinda, B.; Mohanta, B.C.; Ghosh, P.; Sato, N.; Harigaya, Y. ChemInform Abstract: Chemical Constituents of Parkia javanica, Alocasia indica and Premna latifolia. ChemInform 2011, 42. [CrossRef]

111. Tringali, C.; Spatafora, C.; Longo, O.D. Bioactive constituents of the bark of Parkia biglobosa. Fitoterapia 2000, 71, 118-125. [CrossRef]

112. Kamisah, Y.; Zuhair, J.S.F.; Juliana, A.H.; Jaarin, K. Parkia speciosa empty pod prevents hypertension and cardiac damage in rats given N(G)-nitro-L-arginine methyl ester. Biomed. Pharmacother. 2017, 96, 291-298. [CrossRef]

113. Adewoye, R.O.; Ajayi, O.O. Flavonols, flavones and tannins of Parkia clapperoniana. J. Am. Leather Chem. Assoc. (USA) 1988, 83, 153-156.

114. Adewoye, R.O.; Ajayi, O.O. Anthocyanidins of Parkia clappertoniana. J. Soc. Leather Technol. Chem. 1989, 73, $120-121$.

115. Lemmich, E.; Adewunmi, C.O.; Furu, P.; Kristensen, A.; Larsen, L.; Olsen, C.E. 5-Deoxyflavones from Parkia clappertoniana. Phytochemistry 1996, 42, 1011-1013. [CrossRef]

116. Ouoba, L.I.I.; Diawara, B.; Annan, N.T.; Poll, L.; Jakobsen, M. Volatile compounds of Soumbala, a fermented African locust bean (Parkia biglobosa) food condiment. J. Appl. Microbiol. 2005, 99, 1413-1421. [CrossRef] [PubMed]

117. Mohd Azizi, C.Y.; Salman, Z.; Nik Norulain, N.; Mohd Omar, A. Extraction and identification of compounds from Parkia Speciosa seeds by supercritical carbon dioxide. J. Chem. Nat. Resour. Eng. 2008, 2, 153-163.

118. Bitchi, M.B.; Magid, A.A.; Yao-Kouassi, P.A.; Kabran, F.A.; Harakat, D.; Martinez, A.; Morjani, H.; Tonzibo, F.Z.; VoutquenneNazabadioko, L. Triterpene saponins from the roots of Parkia bicolor A. Chev. Fitoterapia 2019, 137, 104264. [CrossRef] [PubMed]

119. Rahman, N.N.N.A.; Zhari, S.; Sarker, M.Z.I.; Ferdosh, S.; Yunus, M.A.C.; Kadir, M.O.A. Profile of Parkia speciosa hassk metabolites extracted with SFE using FTIR-PCA method. J. Chin. Chem. Soc. 2012, 59, 507-514. [CrossRef]

120. Jamaluddin, F.; Mohamed, S.; Lajis, M.N. Hypoglycaemic effect of Parkia speciosa seeds due to the synergistic action of $\beta$-sitosterol and stigmasterol. Food Chem. 1994, 49, 339-345. [CrossRef]

121. Akintayo, E.T. Characteristics and composition of Parkia biglobbossa and Jatropha curcas oils and cakes. Bioresour. Technol. 2004, 92, 307-310. [CrossRef]

122. Olatunya, A.M.; Omojola, A.; Akinpelu, K.; Akintayo, E.T. Vitamin E, Phospholipid, and Phytosterol Contents of Parkia biglobosa and Citrullus colocynthis Seeds and Their Potential Applications to Human Health. Prev. Nutr. Food Sci. 2019, 24, 338-343. [CrossRef]

123. Jamaluddin, F.; Mohameda, S.; Lajis, M.N. Hypoglycaemic effect of Stigmast-4-en-3-one, from Parkia speciosa empty pods. Food Chem. 1995, 54, 9-13. [CrossRef]

124. Salman, Z.; Mohd Azizi, C.; Nik Norulaini, N.; Mohd Omar, A. Gas chromatography/time-of-flight mass spectrometry for identification of compounds from Parkia speciosa seeds extracted by supercritical carbon dioxide. In Proceedings of the First International Conference on Natural Resources Engineering \& Technology, Putrajaya, Malaysia, 24-25 July 2006 ; pp. 112-120.

125. Frérot, E.; Velluz, A.; Bagnoud, A.; Delort, E. Analysis of the volatile constituents of cooked petai beans (Parkia speciosa) using high-resolution GC/ToF-MS. Flavour Fragr. J. 2008, 23, 434-440. [CrossRef]

126. Gmelin, R.; Susilo, R.; Fenwick, G.R. Cyclic polysulphides from Parkia speciosa. Phytochemistry 1981, 20, 2521-2523. [CrossRef]

127. Miyazawa, M.; Osman, F. Headspace constituents of Parkia speciosa seeds. Nat. Prod. Lett. 2001, 15, 171-176. [CrossRef] [PubMed]

128. Tocmo, R.; Liang, D.; Wang, C.; Poh, J.; Huang, D. Organosulfide profile and hydrogen sulfide-releasing capacity of stinky bean (Parkia speciosa) oil: Effects of pH and extraction methods. Food Chem. 2016, 190, 1123-1129. [CrossRef] [PubMed] 
129. Adeyeye, E.I. The effect of fermentation on the dietary quality of lipids from African locust bean (Parkia biglobosa) seeds. Elixir Food Sci. 2013, 58, 14912-14922.

130. Olatunya, A.M.; Akintayo, C.O.; Akintayo, E.T. Determination of qualitative and quantitative fatty acid composition of Parkia biglobbossa seed oil using two different analytical techniques. Int. J. Adv. Res. 2015, 3, 463-473.

131. Millogo-Kone, H.; Guissou, I.; Nacoulma, O.; Traore, A. Comparative study of leaf and stem bark extracts of Parkia biglobosa against enterobacteria. Afr. J. Tradit. Complementary Altern. Med. 2008, 5, 238-243. [CrossRef]

132. Yahaya, U.; Abubakar, S.; Salisu, A. Antifungal activity of Parkia biglobosa extract on pathogenic strain of Candida albicans. J. Appl. Sci. 2019, 19, 235-240. [CrossRef]

133. Bukar, A.; Uba, A.; Oyeyi, T.I. Phytochemical analysis and antimicrobial activity of Parkia biglobosa (Jacq.) Benth. extracts againt some food-borne microrganisms. Adv. Environ. Biol. 2010, 74-80.

134. Joshua, E.; Joshua, E.; Ifeanyichukwu, I.; Chika, E.; Okoro, N.; Carissa, D.; Emmanuel, N.; Chukwuka, A. In vitro evaluation of antibacterial activity of Parkia biglobosa, Hymenocardia acida and Zanthoxylum zanthoxyloides extracts on pathogenic Staphylococcus aureus Isolates. Int. J. Life Sci. 2016, 5, 72-77.

135. Nounagnon, M.; Dah-Nouvlessounon, D.; N'tcha, C.; Nanoukon, C.; Assogba, F.; Lalèyè, F.O.A.; Baba-Moussa, L. Phytochemical composition, antimicrobial and cytotoxicity activities of Parkia biglobosa (Jacq) benth extracts from Benin. J. Pharmacogn. Phytochem. 2017, 6, 35-42.

136. Millogo-Kone, H.; Lompo, M.; Kini, F.; Asimi, S.; Guissou, I.P.; Nacoulma, O. Evaluation of flavonoids and total phenolic contents of stem bark and leaves of Parkia biglobosa (Jacq.) Benth.(Mimosaceae)-free radical scavenging and antimicrobial activities. Res. J. Med Sci. 2009, 3, 70-74.

137. Obajuluwa, A.F.; Onaolapo, J.A.; Oyi, A.R.; Olayinka, B.O. Susceptibility profile of methicillin-resistant Staphylococcus aureus (MRSA) isolates to antibiotics and methanolic extracts of Parkia biglobosa (Jacq.) Benth. Br. J. Pharm. Res. 2013, 3, 587-596. [CrossRef]

138. Dosumu, O.O.; Oluwaniyi, O.O.; Awolola, G.V.; Oyedeji, O.O. Nutritional composition and antimicrobial properties of three Nigerian condiments. Niger. Food J. 2012, 30, 43-52. [CrossRef]

139. Osemwegie, O.O.; Dahunsi, S.O. In-vitro effects of aqueous and ethanolic extracts of Parkia biglobossa (Jacq.) Benth on selected microorganisms. Niger. J. Biotechnol. 2015, 11-20. [CrossRef]

140. Igwo-Ezikpe, M.N.; Ogbunugafor, H.A.; Gureje, A.P.; Ezeonwumelu, I.J. Phytochemical, antioxidant and antimicrobial properties of Parkia biglobosa (African Locust Bean) pods. Bioscientist 2013, 1, 182-191.

141. Farias, D.F.; Souza, T.M.; Viana, M.P.; Soares, B.M.; Cunha, A.P.; Vasconcelos, I.M.; Ricardo, N.M.P.S.; Ferreira, P.M.P.; Melo, V.M.M.; Carvalho, A.F.U. Antibacterial, antioxidant, and anticholinesterase activities of plant seed extracts from Brazilian semiarid region. Biomed Res. Int. 2013, 2013, 510736. [CrossRef]

142. Silva, R.R.S.; Silva, C.R.; Santos, V.F.; Barbosa, C.R.S.; Muniz, D.F.; Santos, A.L.E.; Santos, M.H.C.; Rocha, B.A.M.; Batista, K.L.R.; Costa-Júnior, L.M.; et al. Parkia platycephala lectin enhances the antibiotic activity against multi-resistant bacterial strains and inhibits the development of Haemonchus contortus. Microb. Pathog. 2019, 135, 103629. [CrossRef]

143. Musa, N.; Wei, L.S.; Seng, C.T.; Wee, W.; Leong, L.K. Potential of Edible Plants as Remedies of Systemic Bacterial Disease Infection in Cultured Fish. Glob. J. Pharmacol. 2008, 2, 31-36.

144. Sakunpak, A.; Panichayupakaranant, P. Antibacterial activity of Thai edible plants against gastrointestinal pathogenic bacteria and isolation of a new broad spectrum antibacterial polyisoprenylated benzophenone, chamuangone. Food Chem. 2012, 130, 826-831. [CrossRef]

145. Fatimah, I. Green synthesis of silver nanoparticles using extract of Parkia speciosa Hassk pods assisted by microwave irradiation. J. Adv. Res. 2016, 7, 961-969. [CrossRef] [PubMed]

146. Ravichandran, V.; Vasanthi, S.; Shalini, S.; Shah, S.A.A.; Tripathy, M.; Paliwal, N. Green synthesis, characterization, antibacterial, antioxidant and photocatalytic activity of Parkia speciosa leaves extract mediated silver nanoparticles. Results Phys. 2019, 15, 102565. [CrossRef]

147. Kawamura, F.; Ramle, S.F.M.; Sulaiman, O.; Hashim, R.; Ohara, S. Antioxidant and antifungal activities of extracts from 15 selected hardwood species of Malaysian timber. Eur. J. Wood Wood Prod. 2011, 69, 207-212. [CrossRef]

148. Hasim, H.; Faridah, D.N. Antibacterial activity of Parkia speciosa Hassk. peel to Escherichia coli and Staphylococcus aureus bacteria. J. Chem. Pharm. Res. 2015, 7, 239-243.

149. Thongbam, P.D.; Shakuntala, I.; Fiyaz, A.R.; Moirangthem, S.S.; Pajat, J.J.; Ngachan, S.V. Tree bean (Parkia roxburghii G. Don): A complete food and ethno-medicine for North East India. Res. Bull. 2012, 12-14.

150. Zuhud, E.A.M.; Rahayu, W.P.; Wijaya, C.H.; Sari, P.P. Antimicrobial activity of kedawung extract (Parkia roxburghii G. Don) on food borne pathogens. J. Teknol. Dan Ind. Pangan 2001, 12, 1-5.

151. Paul, B.; Bhuyan, B.; Purkayastha, D.D.; Dhar, S.S. Photocatalytic and antibacterial activities of gold and silver nanoparticles synthesized using biomass of Parkia roxburghii leaf. J. Photochem. Photobiol. B Biol. 2016, 154, 1-7. [CrossRef]

152. Devi, T.P.; Shakuntala, I.; Devi, G.; Nonglait, K.K.L.; Singha, L.B.; Pattanayak, A.; Rahman, H. Antibacterial, nematicidal and nutritional properties of different parts of tree bean, Parkia roxburghii G. Don. Asian J. Microbiol. Biotechnol. Environ. Sci 2007, 9, 621-626.

153. Shrisha, D.L.; Raveesha, K.A. Nagabhushan Bioprospecting of selected medicinal plants for antibacterial activity against some pathogenic bacteria. J. Med. Plants Res. 2011, 5, 4087-4093. 
154. Patel, J.R.; Gohil, T.G. Antibacterial efficacy of methanolic leaf extracts of some trees against some common pathogenic bacteria. J. Appl. Sci. Comput. 2018, 5, 404-408.

155. Behuria, H.G.; Sahu, S.K. An Anti-microbial terpenoid fraction from Gymnema sylvestre induces flip-flop of fluorescentphospholipid analogs in model membrane. Appl. Biochem. Biotechnol. 2020, 192, 1331-1345. [CrossRef] [PubMed]

156. Tunsaringkarn, T.; Rungsiyothin, A.; Ruangrungs, N. $\alpha$-glucosidase inhibitory activity of Thai mimosaceous plant extracts J. Health Res. 2008, 22, 29-33.

157. Jamaluddin, F.; Mohameda, S. Hypoglycemic effect of extracts of petai papan (Parkia speciosa, Hassk). Agric. Sci. 1993, 16, 161.

158. Fitria, F.; Annisa, A.; Nikita, S.; Ranna, C. Alpha glukosidase inhibitory test and total phenolic content of ethanol extract of Parkia speciosa plant. Sci. Technol. Indones. 2019, 4, 1. [CrossRef]

159. Saleh, M.S.M.; Siddiqui, M.J.; Mat So'ad, S.Z.; Roheem, F.O.; Saidi-Besbes, S.; Khatib, A. Correlation of FT-IR fingerprint and $\alpha$-glucosidase inhibitory activity of salak (Salacca zalacca) fruit extracts utilizing orthogonal partial least square. Molecules 2018, 23, 1434. [CrossRef] [PubMed]

160. Ramu, R.; Shirahatti, P.S.; Nayakavadi, S.; Vadivelan, R.; Zameer, F.; Dhananjaya, B.L.; Nagendra Prasad, M.N. The effect of a plant extract enriched in stigmasterol and $\beta$-sitosterol on glycaemic status and glucose metabolism in alloxan-induced diabetic rats. Food Funct. 2016, 7, 3999-4011. [CrossRef] [PubMed]

161. Wang, J.; Huang, M.; Yang, J.; Ma, X.; Zheng, S.; Deng, S.; Huang, Y.; Yang, X.; Zhao, P. Anti-diabetic activity of stigmasterol from soybean oil by targeting the GLUT4 glucose transporter. Food Nutr. Res. 2017, 61. [CrossRef]

162. Ward, M.G.; Li, G.; Barbosa-Lorenzi, V.C.; Hao, M. Stigmasterol prevents glucolipotoxicity induced defects in glucose-stimulated insulin secretion. Sci. Rep. 2017, 7, 1-13. [CrossRef]

163. Aiyer, P.V. Amylases and their applications. Afr. J. Biotechnol. 2005, 4, 1525-1529.

164. Odetola, A.A.; Akinloye, O.; Egunjobi, C.; Adekunle, W.A.; Ayoola, A.O. Possible antidiabetic and antihyperlipidaemic effect of fermented Parkia biglobosa (Jacq) ex- tract in alloxan induced diabetic rats. Clin. Exp. Pharmacol. Physiol. 2006, 33, 808-812. [CrossRef]

165. Sule, O.; Godwin, J.; Abdu, A. Preliminary study of hypoglycemic effect of locust bean (Parkia biglobosa) on wistar albino rat. J. Sci. Res. Rep. 2015, 4, 467-472. [CrossRef]

166. Ibrahim, M.A.; Habila, J.D.; Koorbanally, N.A.; Islam, M.S. Butanol fraction of Parkia biglobosa (Jacq.) G. Don leaves enhance pancreatic $\beta$-cell functions, stimulates insulin secretion and ameliorates other type 2 diabetes-associated complications in rats. J. Ethnopharmacol. 2016, 183, 103-111. [CrossRef] [PubMed]

167. Chanvitan, A.; Ubolcholket, S.; Chongsuvivatwong, V.; Geater, A. Risk factors for squamous cell carcinoma in southern Thailand. Esophageal Canver Stud. South. Thail. 1990, 81-100.

168. Tangkanakul, P.; Trakoontivakorn, G.; Saengprakai, J.; Auttaviboonkul, P.; Niyomwit, B.; Lowvitoon, N.; Nakahara, K. Antioxidant capacity and antimutagenicity of thermal processed Thai foods. Jpn. Agric. Res. Q. JARQ 2011, 45, 211-218. [CrossRef]

169. Murakami, A.; Ohigashi, H.; Koshimizu, K. Possible anti-tumour promoting properties of traditional Thai food items and some of their active constituents. Asia Pac. J. Clin. Nutr. 1994, 3, 185-191.

170. Aisha, A.F.A.; Abu-Salah, K.M.; Alrokayan, S.A.; Ismail, Z.; Abdul Majid, A.M.S. Evaluation of antiangiogenic and antoxidant properties of Parkia speciosa Hassk extracts. Pak. J. Pharm. Sci. 2012, 25, 7-14.

171. Singh, R.S.; Bhari, R.; Kaur, H.P. Mushroom lectins: Current status and future perspectives. Crit. Rev. Biotechnol. 2010, 30, 99-126. [CrossRef]

172. Suvachittanont, W.; Jaranchavanapet, P. Mitogenic effect of Parkia speciosa seed lectin on human lymphocytes. Planta Med. 2000, 66, 699-704. [CrossRef]

173. Kaur, N.; Singh, J.; Kamboj, S.; Agrewala, J.; Kaur, M. Two Novel Lectins from Parkia biglandulosa and Parkia roxburghii: Isolation, Physicochemical Characterization, Mitogenicity and Anti- Proliferative Activity. Protein Pept. Lett. 2005, 12, 589-595. [CrossRef]

174. Fadeyi, S.A.; Fadeyi, O.O.; Adejumo, A.A.; Okoro, C.; Myles, E.L. In vitro anticancer screening of 24 locally used Nigerian medicinal plants. BMC Complementary Altern. Med. 2013, 13, 79. [CrossRef]

175. Shete, S.V.; Mundada, S.J.; Dhande, S. Comparative effect of crude extract of Parkia biglandulosa and Its isolate on regenerative angiogenesis In adult Zebrafish. Indian Drug 2017, 54, 51-57.

176. Kamisah, Y.; Othman, F.; Qodriyah, H.M.S.; Jaarin, K. Parkia speciosa Hassk.: A potential phytomedicine. Evid. Based Complementary Altern. Med. 2013, 2013, 709028. [CrossRef] [PubMed]

177. Auyeung, K.K.; Han, Q.-B.; Ko, J.K. Astragalus membranaceus: A review of its protection against inflammation and gastrointestinal cancers. Am. J. Chin. Med. 2016, 44, 1-22. [CrossRef] [PubMed]

178. Ognatan, K.; Adi, K.; Lamboni, C.; Damorou, J.M.; Aklikokou, K.A.; Gbeassor, M.; Guilland, J.C. Effect of dietary intake of fermented seeds of Parkia biglobosa (Jacq) Benth (African locust bean) on hypertension in bogou and goumou-kope areas of togo. Trop. J. Pharm. Res. 2011, 10, 603-609. [CrossRef]

179. Kodjo, K.M.; Contesse, V.; Do Rego, J.L.; Aklikokou, K.; Titrikou, S.; Gbeassor, M.; Vaudry, H. In vitro effects of crude extracts of Parkia biglobosa (Mimosaceae), Stereospermum kunthianum (Bignoniaceae) and Biophytum petersianum (Oxalidaceae) on corticosteroid secretion in rat. J. Steroid Biochem. Mol. Biol. 2006, 100, 202-208. [CrossRef]

180. Ouédraogoa, S.; Somé, N.; Ouattara, S.; Kini, F.B.; Traore, A.; Bucher, B.; Guissou, I.P. Acute toxicity and vascular properties of seed of Parkia biglobosa (JACQ) R. Br Gift (Mimosaceae) on rat aorta. Afr. J. Tradit. Complementary Altern. Med. 2012, 9, $260-265$. 
181. Kassi, Y.; Aka, K.J.; Abo, K.J.C.; Mea, A.; Bi, S.A.N.; Ehile, E.E. Effet antihypertensif d'un extrait aqueux d'écorce de tronc de Parkia biglobosa (mimosaceae) sur la pression artérielle de lapin. Sci. Nat. 2008, 5, 133-143.

182. Yi, Q.Y.; Li, H.B.; Qi, J.; Yu, X.J.; Huo, C.J.; Li, X.; Bai, J.; Gao, H.L.; Kou, B.; Liu, K.L.; et al. Chronic infusion of epigallocatechin-3$\mathrm{O}$-gallate into the hypothalamic paraventricular nucleus attenuates hypertension and sympathoexcitation by restoring neurotransmitters and cytokines. Toxicol. Lett. 2016, 262, 105-113. [CrossRef]

183. Galleano, M.; Pechanova, O.; G Fraga, C. Hypertension, nitric oxide, oxidants, and dietary plant polyphenols. Curr. Pharm. Biotechnol. 2010, 11, 837-848. [CrossRef]

184. Takagaki, A.; Nanjo, F. Effects of Metabolites Produced from (-)-Epigallocatechin Gallate by Rat Intestinal Bacteria on Angiotensin I-Converting Enzyme Activity and Blood Pressure in Spontaneously Hypertensive Rats. J. Agric. Food Chem. 2015, 63, 8262-8266. [CrossRef]

185. Luo, D.; Xu, J.; Chen, X.; Zhu, X.; Liu, S.; Li, J.; Xu, X.; Ma, X.; Zhao, J.; Ji, X. (-)-Epigallocatechin-3-gallate (EGCG) attenuates salt-induced hypertension and renal injury in Dahl salt-sensitive rats. Sci. Rep. 2020, 10, 1-11. [CrossRef] [PubMed]

186. Ayo-Lawal, R.A.; Osoniyi, O.; Famurewa, A.J.; Lawal, O.A. Evaluation of antioxidant and hypolipidaemic effects of fermented Parkia biglobosa (Jacq) seeds in tyloxapol-induced hyperlipidaemic rats. Afr. J. Food Sci. 2014, 8, 225-232. [CrossRef]

187. Rendu, F.; Saleun, S.; Auger, J. Parkia biglobosa seeds possess anti platelet activity. Thromb. Res. 1993, 71, 505-508. [CrossRef]

188. Appeldoorn, M.M.; Venema, D.P.; Peters, T.H.F.; Koenen, M.E.; Arts, I.C.W.; Vincken, J.P.; Gruppen, H.; Keuer, J.; Hollman, P.C.H. Some phenolic compounds increase the nitric oxide level in endothelial cells in vitro. J. Agric. Food Chem. 2009, 57, 7693-7699. [CrossRef]

189. Siow, H.L.; Gan, C.Y. Extraction of antioxidative and antihypertensive bioactive peptides from Parkia speciosa seeds. Food Chem. 2013, 141, 3435-3442. [CrossRef]

190. Zaini, N.; Mustaffa, F. Review: Parkia speciosa as Valuable, Miracle of Nature. Asian J. Med. Health 2017, 2, 1-9. [CrossRef]

191. Khalid, N.M.; Babji, A.S. Antioxidative and antihypertensive activities of selected Malaysian ulam (salad), vegetables and herbs. J. Food Res. 2018, 7, 27-37. [CrossRef]

192. Owolabi, O.J.; Ukoima, G.S.; Inninh, S.O.; Otokiti, I.O. The anti-diarrhoeal activity of the aqueous stem bark extract of Parkia filicoidea (Fabaceae). J. Med. Biomed. Res. 2016, 15, 12-20.

193. Adebayo, O.L.; Marzuk, S.; Mumuni, S.I. An in vivo assessment of Anti-diarrheal activity of solvent extracts of leaf and stem bark of Ghanian Parkia biglobosa against castor oil induced diarrhea in albino rats. Int. J. Bioassays 2014, 310, $3358-3362$.

194. Sahoo, H.B.; Sagar, R.; Kumar, A.; Bhaiji, A.; Bhattamishra, S.K. Antidiarrhoeal investigation of Apium leptophyllum (Pers.) by modulation of $\mathrm{Na}+\mathrm{K}+\mathrm{ATPase}$, nitrous oxide and intestinal transit in rats. Biomed. J. 2016, 39, 376-381. [CrossRef]

195. Khan, T.; Ali, S.; Qayyum, R.; Hussain, I.; Wahid, F.; Shah, A.J. Intestinal and vascular smooth muscle relaxant effect of Viscum album explains its medicinal use in hyperactive gut disorders and hypertension. BMC Complementary Altern. Med. 2016, 16, 1-8. [CrossRef] [PubMed]

196. Imtiaz, S.M.; Aleem, A.; Saqib, F.; Ormenisan, A.N.; Neculau, A.E.; Anastasiu, C.V. The potential involvement of an ATPdependent potassium channel-opening mechanism in the smooth muscle relaxant properties of Tamarix dioica roxb. Biomolecules 2019, 9, 722. [CrossRef] [PubMed]

197. Maria, M.S.; Devarakonda, S.; Kumar, A.T.V.; Balakrishnan, N. Anti-ulcer activity of ethanol extract of Parkia speciosa against indomethacin induced peptic ulcer in albino rats. Int. J. Pharm. Sci. Res. 2015, 6, 895-902.

198. Al Batran, R.; Al-Bayaty, F.; Al-Obaidi, M.M.J.; Abdualkader, A.M.; Hadi, H.A.; Ali, H.M.; Abdulla, M. A In vivo antioxidant and antiulcer activity of Parkia speciosa ethanolic leaf extract against ethanol-induced gastric ulcer in rats. PLoS ONE 2013, 8, e64751. [CrossRef] [PubMed]

199. Fernandes, H.B.; Silva, F.V.; B Passos, F.F.; S Bezerra, R.D.; Chaves, M.H.; Oliveira, F.A.; Meneses Oliveira, R.C. Gastroprotective effect of the ethanolic extract of Parkia platycephala benth. Leaves against acute gastric lesion models in rodents. Biol. Res. 2010, 43, 451-457. [CrossRef] [PubMed]

200. Hamaishi, K.; Kojima, R.; Ito, M. Anti-ulcer effect of tea catechin in rats. Biol. Pharm. Bull. 2006, 29, 2206-2213. [CrossRef]

201. Ito, Y.; Ichikawa, T.; Iwai, T.; Saegusa, Y.; Ikezawa, T.; Goso, Y.; Ishihara, K. Effects of tea catechins on the gastrointestinal mucosa in rats. J. Agric. Food Chem. 2008, 56, 12122-12126. [CrossRef]

202. Suzuki, Y.; Ishihara, M.; Segami, T.; Ito, M. Anti-ulcer effects of antioxidants, quercetin, $\alpha$-tocopherol, nifedipine and tetracycline in rats. Jpn. J. Pharmacol. 1998, 78, 435-441. [CrossRef]

203. De Barros, M.P.; Lemos, M.; Maistro, E.L.; Leite, M.F.; Sousa, J.P.B.; Bastos, J.K.; de Andrade, S.F. Evaluation of antiulcer activity of the main phenolic acids found in Brazilian Green Propolis. J. Ethnopharmacol. 2008, 120, 372-377. [CrossRef]

204. Ijarotimi, O.S.; Keshinro, O.O. Protein quality, hematological properties and nutritional status of albino rats fed complementary foods with fermented popcorn, African locust bean, and bambara groundnut flour blends. Nutr. Res. Pract. 2012, 6, 381-388. [CrossRef]

205. Nursucihta, S.; Thai'in, H.A.; Putri, D.M.; Utami, D.N.; Ghani, A.P. Antianemia activity of parkia speciosa hassk seed ethanolic extract. Maj. Obat Tradis. 2014, 19, 49-54.

206. Nwaehujor, C.O.; Ezeigbo, I.I.; Udeh, N.E.; Ezeja, M.I.; Asuzu, I.U. Anti-inflammatory anti-oxidant Activities of the methanolic extracts of the stalk of Parkia biglobosa. Hygein J. Med. 2010, 3, 34-40. 
207. Bari, A.U.; Santiago, M.Q.; Osterne, V.J.S.; Pinto-Junior, V.R.; Pereira, L.P.; Silva-Filho, J.C.; Debray, H.; Rocha, B.A.M.; Delatorre, P.; Teixeira, C.S.; et al. Lectins from Parkia biglobosa and Parkia platycephala: A comparative study of structure and biological effects. Int. J. Biol. Macromol. 2016, 92, 194-201. [CrossRef] [PubMed]

208. Silva, H.C.; Bari, A.U.; Rocha, B.A.M.; Nascimento, K.S.; Ponte, E.L.; Pires, A.F.; Delatorre, P.; Teixeira, E.H.; Debray, H.; Assreuy, A.M.S. Purification and primary structure of a mannose/glucose-binding lectin from Parkia biglobosa Jacq. seeds with antinociceptive and anti-inflammatory properties. J. Mol. Recognit. 2013, 26, 470-478. [CrossRef] [PubMed]

209. Ukwuani, A.; Ahmad, H. In vitro anti-inflammatory activity of Parkia biglobosa fruit bark extract. Int. J. Life Sci. Sci. Res. 2015, 1, 8-11. [CrossRef]

210. Badu, M.; Mensah, J.K.; Boadi, N.O. Antioxidant activity of methanol and ethanol/water extracts of Tetrapleura tetraptera and Parkia biglobosa. Int. J. Pharma Bio Sci. 2012, 3, 312-321.

211. Oboh, G.; Alabi, K.B.; Akindahunsi, A.A. Fermentation changes the nutritive value, polyphenol distribution, and antioxidant properties of Parkia biglobosa seeds (African locust beans). Food Biotechnol. 2008, 22, 363-376. [CrossRef]

212. Seal, T. Antioxidant activity of some wild edible plants of Meghalaya state of India: A comparison using two solvent extraction systems. Int. J. Nutr. Metab. 2012, 4, 51-56.

213. Ghasemzadeh, A.; Jaafar, H.Z.E.; Bukhori, M.F.M.; Rahmat, M.H.; Rahmat, A. Assessment and comparison of phytochemical constituents and biological activities of bitter bean (Parkia speciosa Hassk.) collected from different locations in Malaysia. Chem. Cent. J. 2018, 12, 1-9. [CrossRef]

214. Bajpai, V.K.; Alam, B.; Ju, M.; Kwon, K.; Suk, Y. Antioxidant mechanism of polyphenol-rich Nymphaea nouchali leaf extract protecting DNA damage and attenuating oxidative stress-induced cell death via Nrf2-mediated heme-oxygenase-1 induction coupled with ERK/p38 signaling pathway. Biomed. Pharmacother. 2018, 103, 1397-1407. [CrossRef]

215. Tunsaringkarn, T.; Soogarun, S.; Rungsiyothin, A.; Palasuwan, A. Inhibitory activity of Heinz body induction in vitro antioxidant model and tannin concentration of Thai mimosaceous plant extracts. J. Med. Plants Res. 2012, 6, 4096-4101. [CrossRef]

216. Ajibola, M.; Olugbemi, O.; Joseph, D.; Denen, A. Hepatoprotective effect of Parkia biglobosa stem bark methanolic extract on paracetamol induced liver damage in wistar rats. Am. J. Biomed. Life Sci 2013, 1, 75-78. [CrossRef]

217. Coriolano, M.C.; de Melo, C.M.L.; de Oliveira Silva, F.; Schirato, G.V.; Porto, C.S.; dos Santos, P.J.P.; dos Santos Correia, M.T.; Porto, A.L.F.; dos Anjos Carneiro-Leão, A.M.; Coelho, L.C.B.B. Parkia pendula seed lectin: Potential use to treat cutaneous wounds in healthy and immunocompromised mice. Appl. Biochem. Biotechnol. 2014, 172, 2682-2693. [CrossRef] [PubMed]

218. Angami, T.; Bhagawati, R.; Touthang, L.; Makdoh, B.; Nirmal; Lungmuana; Bharati, K.A.; Silambarasan, R.; Ayyanar, M. Traditional uses, phytochemistry and biological activities of Parkia timoriana (DC.) Merr., an underutilized multipurpose tree bean: A review. Genet. Resour. Crop Evol. 2018, 65, 679-692. [CrossRef]

219. Hopkins, H.C. Floral biology and pollination ecology of the neotropical species of Parkia. J. Ecol. 1984, 72, 1-23. [CrossRef]

220. Abalaka, S.E.; Fatihu, M.Y.; Ibrahim, N.D.G.; Kazeem, H.M. Histopathologic changes in the gills and skin of adult Clarias gariepinus exposed to ethanolic extract of Parkia biglobosa pods. Basic Appl. Pathol. 2010, 3, 109-114. [CrossRef]

221. Oshimagye, M.I.; Ayuba, V.O.; Annune, P.A. Toxicity of aqueous extracts of Parkia biglobosa pods on Clarias gariepinus (Burchell, 1822) Juveniles. Niger. J. Fish. Aquac. 2014, 2, 24-29.

222. Uyub, A.M.; Nwachukwu, I.N.; Azlan, A.A.; Fariza, S.S. In-vitro antibacterial activity and cytotoxicity of selected medicinal plant extracts from Penang Island Malaysia on some pathogenic bacteria. Ethnobot. Res. Appl. 2010, 8, 95-106. [CrossRef]

223. Sil, S.K.; Saha, S.; Karmakar, P. Reactive oxygen species as possible mediator of antibacterial activity of Parkia javanica, against bacterial species predominantly found in chronic wound. J. Drug Deliv. Ther. 2018, 8, 43-47. [CrossRef]

224. Rupanjali, S.; Basu, J.M.; Syamal, R.; Biswanath, D.; Sil, S.K. In vitro activity of Parkia javanica extract against Leishmania donovani parasite. J. Appl. Biosci. 2010, 36, 85-89.

225. Favacho, A.R.M.; Cintra, E.A.; Coelho, L.C.B.B.; Linhares, M.I.S. In vitro activity evaluation of Parkia pendula seed lectin against human cytomegalovirus and herpes virus 6. Biologicals 2007, 35, 189-194. [CrossRef] [PubMed]

226. Ogunyinka, B.I.; Oyinloye, B.E.; Osunsanmi, F.O.; Opoku, A.R.; Kappo, A.P. Modulatory influence of Parkia biglobosa protein isolate on testosterone and biomarkers of oxidative stress in brain and testes of streptozotocin-induced diabetic male rats Bolajoko. Int. J. Physiol. Pathophysiol. Pharm. 2016, 8, 78-86. [CrossRef]

227. Patra, K.; Jana, S.; Sarkar, A.; Karmakar, S.; Jana, J.; Gupta, M.; Mukherjee, G.; De, U.C.; Mandal, D.P.; Bhattacharjee, S. Parkia javanica extract induces apoptosis in S-180 cells via the intrinsic pathway of apoptosis. Nutr. Cancer 2016, 68, 689-707. [CrossRef] [PubMed]

228. Aisha, A.F.A.; Abu-Salah, K.M.; Darwis, Y.; Majid, A.M.S.A. Screening of antiangiogenic activity of some tropical plants by rat aorta ring assay. Int. J. Pharmacol. 2009, 5, 370-376. [CrossRef]

229. Gui, J.S.; Jalil, J.; Jubri, Z.; Kamisah, Y. Parkia speciosa empty pod extract exerts anti-inflammatory properties by modulating NFkB and MAPK pathways in cardiomyocytes exposed to tumor necrosis factor- $\alpha$. Cytotechnology 2019, 71, 79-89. [CrossRef]

230. Mustafa, N.H.; Ugusman, A.; Jalil, J.; Kamisah, Y. Anti-inflammatory property of Parkia speciosa empty pod extract in human umbilical vein endothelial cells. J. Appl. Pharm. Sci. 2018, 8, 152-158. [CrossRef]

231. Ruthiran, P.; Selvaraj, C.I. Phytochemical screening and in vitro antioxidant activity of Parkia timoriana (DC.) Merr. Res. J. Biotechnol. 2017, 12, 12.

232. Chanu, K.V.; Ali, M.A.; Kataria, M. Antioxidant activities of two medicinal vegetables: Parkia javanica and Phlogacanthus thyrsiflorus. Int. J. Pharm. Pharm. Sci. 2012, 4, 102-106. 
233. Balaji, K.; Nedumaran, S.A.; Devi, T.; Sikarwar, M.S.; Fuloria, S. Phytochemical analysis and in vitro antioxidant activity of Parkia speciosa. Int. J. Green Pharm. 2015, 9, S50-S54. [CrossRef]

234. Ramli, S.; Bunrathep, S.; Tansaringkarn, T.; Ruangrungsi, N. Screening for free radical scavenging activity from ethanolic extract of Mimosaceous plants Endemic to Thailand. J. Health Res. 2008, 22, 55-59.

235. Komolafe, K.; Olaleye, T.M.; Omotuyi, O.I.; Boligon, A.A.; Athayde, M.L.; Akindahunsi, A.A.; da Rocha, J.B.T. In vitro antioxidant activity and effect of Parkia biglobosa bark extract on mitochondrial redox status. Jams J. Acupunct. Meridian Stud. 2014, 7, 202-210. [CrossRef] [PubMed] 